DOE/NV/11508-17

UC-703

\title{
ASSESSMENT OF HYDROLOGIC TRANSPORT OF RADIONUCLIDES FROM THE RULISON UNDERGROUND NUCLEAR TEST SITE, COLORADO
}

\author{
prepared by \\ Sam Earman, Jenny Chapman, and Roko Andricevic \\ RECENED \\ MAR 181997 \\ OSTI \\ submitted to \\ Nevada Operations Office \\ U.S. Department of Energy
}

September 1996

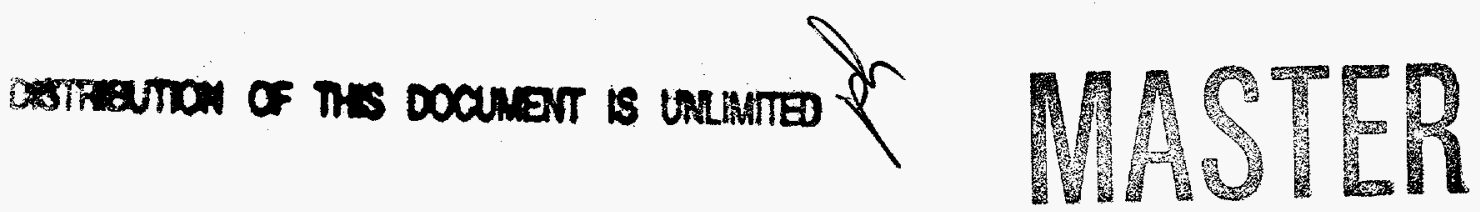

Publication No. 45149 


\section{DECLAMMTR}

Portions of this document may be illegible in electronic image produets. Images are produced from the best available original document. 
This report was prepared as an account of work sponsored by the United States Government. Neither the United States nor the United States Department of Energy, nor any of their employees, makes any warranty, express or implied, or assumes any legal liability or responsibility for the accuracy, completeness or usefulness of any information, apparatus, product or process disclosed, or represents that its use would not infringe privately owned rights. Reference herein to any specific commercial product, process, or service by trade name, mark, manufacturer, or otherwise, does not necessarily constitute or imply its endorsement, recommendation, or favoring by the United States Government or any agency thereof. The views and opinions of authors expressed herein do not necessarily state or reflect those of the United States Government or any agency thereof.

This report has been reproduced directly from the best available copy.

Available to DOE and DOE contractors from the Office of Scientific and Technical Information, P.O. Box 62, Oak Ridge, TN 37831; prices available from (423) 576-8401.

Available to the public from the National Technical Information Service, U.S. Department of Commerce, 5285 Port Royal Rd., Springfield, VA 22161. 


\title{
ASSESSMENT OF HYDROLOGIC TRANSPORT OF RADIONUCLIDES FROM THE RULISON UNDERGROUND NUCLEAR TEST SITE, COLORADO
}

\author{
prepared by \\ Sam Earman, Jenny Chapman, and Roko Andricevic \\ Water Resources Center \\ Desert Research Institute \\ University and Community College System of Nevada
}

Publication No. 45149

submitted to

Nevada Operations Office

U.S. Department of Energy

Las Vegas, Nevada

September 1996

The work upon which this report is based was supported by the U.S. Department of Energy under Contract \#DE-AC08-95NV11508. 


\begin{abstract}
The U.S. Department of Energy (DOE) is operating an environmental restoration program to characterize, remediate, and close non-Nevada Test Site locations that were used for nuclear testing. Evaluation of radionuclide transport by groundwater from these sites is an important part of the preliminary risk analysis. These evaluations are undertaken to allow prioritization of the test areas in terms of risk, provide a quantitative basis for discussions with regulators and the public about future work at the sites, and provide a framework for assessing data needs to be filled by site characterization. The Rulison site in west-central Colorado was the location of an underground detonation of a 40 -kiloton nuclear device in 1969. The test took place 2,568 m below ground surface in the Mesaverde Formation. Though located below the regional water table, none of the bedrock formations at the site yielded water during hydraulic tests, indicating extremely low permeability conditions. The scenario evaluated was the migration of radionuclides from the blast-created cavity through the Mesaverde Formation. Transport calculations were performed using the solute flux method, with input based on the limited data available for the site. Model results suggest that radionuclides from the test are contained entirely within the area currently administered by DOE. The transport calculations are most sensitive to changes in the mean groundwater velocity and the correlation scale of hydraulic conductivity, with transport of strontium and cesium also sensitive to the sorption coefficient. This modeling was performed to investigate how the uncertainty in various physical parameters affects calculations of radionuclide transport at the Rulison site, and to serve as a starting point for discussion regarding further investigation at the site; it was not intended to be a definitive simulation of migration pathways of radionuclide concentration values. Given the sparse data, the modeling results may differ significantly from reality. If needed, confidence in transport predictions can be increased by obtaining more site data, including ascertaining the amount of radionuclides available for transport (i.e., not trapped in melt glass or vented during gas flow testing), and determining accurate values for the mean groundwater velocity, correlation scale for hydraulic conductivity, and sorption coefficients for strontium and cesium.
\end{abstract}




\section{CONTENTS}

ABSTRACT $\ldots \ldots \ldots \ldots \ldots \ldots \ldots \ldots \ldots \ldots \ldots \ldots \ldots \ldots \ldots \ldots \ldots \ldots$

LIST OF FIGURES $\ldots \ldots \ldots \ldots \ldots \ldots \ldots \ldots \ldots \ldots \ldots \ldots \ldots \ldots \ldots \ldots \ldots \ldots$

LIST OF TABLES $\ldots \ldots \ldots \ldots \ldots \ldots \ldots \ldots \ldots \ldots \ldots \ldots \ldots \ldots \ldots \ldots \ldots \ldots$

INTRODUCTION $\ldots \ldots \ldots \ldots \ldots \ldots \ldots \ldots \ldots \ldots \ldots \ldots \ldots \ldots \ldots \ldots \ldots \ldots \ldots \ldots$

METHODOLOGY $\ldots \ldots \ldots \ldots \ldots \ldots \ldots \ldots \ldots \ldots \ldots \ldots \ldots \ldots \ldots \ldots$

HYDROGEOLOGIC SETTING $\ldots \ldots \ldots \ldots \ldots \ldots \ldots \ldots \ldots \ldots \ldots \ldots \ldots$

RELEASE SCENARIO $\ldots \ldots \ldots \ldots \ldots \ldots \ldots \ldots \ldots \ldots \ldots \ldots \ldots \ldots$

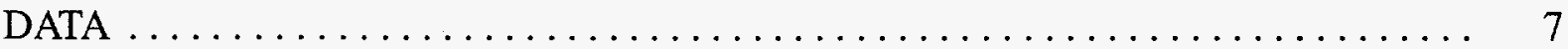

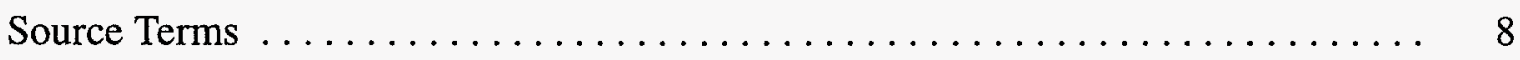

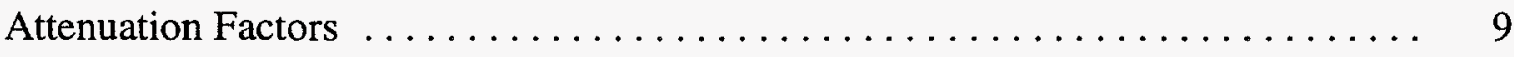

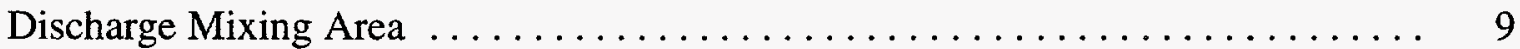

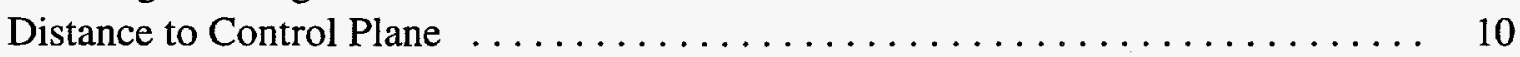

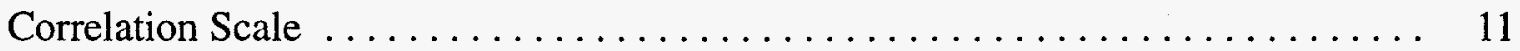

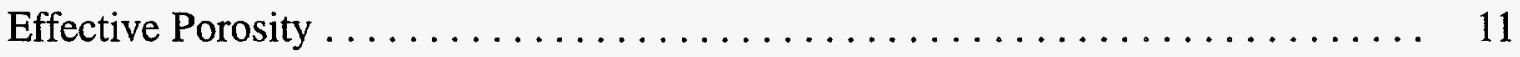

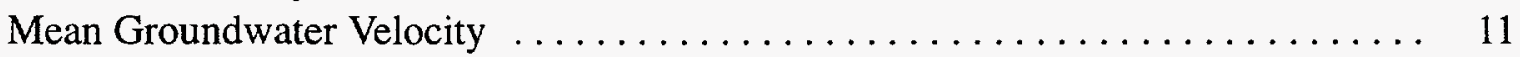

Spatial Variability in Hydraulic Conductivity $\ldots \ldots \ldots \ldots \ldots \ldots \ldots \ldots \ldots \ldots$

RESULTS . . . . . . . . . . . . . . . . . . . . . . . . . . 13

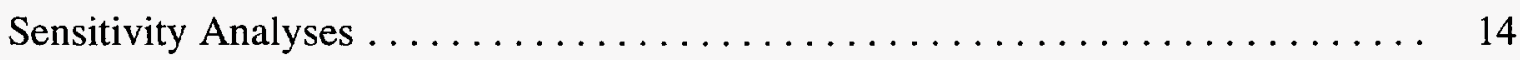

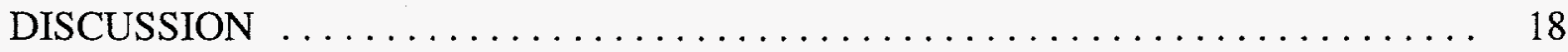

CONCLUSIONS $\ldots \ldots \ldots \ldots \ldots \ldots \ldots \ldots \ldots \ldots \ldots \ldots \ldots \ldots \ldots \ldots \ldots$

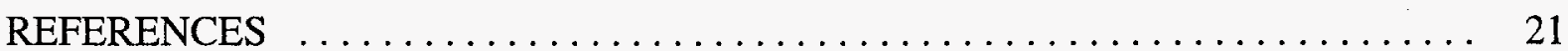




\section{FIGURES}

1. Rulison site location map $\ldots \ldots \ldots \ldots \ldots \ldots \ldots \ldots \ldots \ldots \ldots \ldots \ldots \ldots \ldots \ldots, 2$

2. Generalized geologic cross section at the Rulison emplacement hole . ........ 5

3. Locations of wells R-E and R-EX in SW/4, section $25 \ldots \ldots \ldots \ldots \ldots \ldots$

4. Modeled tritium concentrations at the drilling exclusion boundary resulting from the Rulison test $\ldots \ldots \ldots \ldots \ldots \ldots \ldots \ldots \ldots \ldots \ldots \ldots$

5. Sensitivity of mean tritium concentration $286 \mathrm{~m}$ west of surface ground zero to changes in correlation scale.

6. Sensitivity of mean tritium concentration $286 \mathrm{~m}$ northeast of surface ground zero to changes in mean groundwater velocity. . .

7. Sensitivity of mean tritium concentration $286 \mathrm{~m}$ northeast of surface ground zero to changes in variance. . . . . . . . . . . . . . . . . . . . . . .

8. Sensitivity of mean tritium concentration $286 \mathrm{~m}$ northeast of surface ground zero to changes in the transverse hydrodynamic dispersion coefficient.

\section{TABLES}

1. Well shut-in pressures at selected depths in the mesaverde formation $\ldots \ldots \ldots \ldots 7$

2. Radionuclides produced by the Rulison nuclear test $\ldots \ldots \ldots \ldots \ldots \ldots \ldots$

3. Results of groundwater transport calculations for radionuclides produced by the Rulison test. 


\section{INTRODUCTION}

The U.S. Department of Energy (DOE) and its predecessor agencies are responsible for nuclear weapons research and development as part of the national defense program. These activities include underground nuclear testing, and a small number of such tests have been conducted at sites distant from the Nevada Test Site (NTS). The Rulison site is located in west-central Colorado, approximately $64 \mathrm{~km}$ northeast of Grand Junction (Figure 1). Project Rulison was part of the Plowshare Program, and was designed to increase the natural gas production of a low permeability reservoir formation. The device had a yield of 40 kilotons, and was detonated 2,568 $\mathrm{m}$ below ground surface on September 10, 1969.

DOE has implemented an environmental restoration program with the goal of characterizing, remediating, and closing the offsite nuclear test areas. An early step in this process is performing a preliminary risk analysis of the hazard posed by each site. These analyses will allow prioritization of the sites in terms of risk, provide a quantitative basis for discussions with regulators and the public about future work at the sites, and provide a framework for assessing data needs to be filled by site characterization. Desert Research Institute (DRI) is tasked with performing hydrologic risk evaluations for the groundwater transport pathway. This report details the results of the groundwater-transport evaluation for the Rulison site in terms of radionuclide concentrations that could cross the site boundary. These results will be included with evaluations of risk due to surface sources at Rulison to present a comprehensive site risk analysis in a separate report.

The basic scenario evaluated for this assessment is the groundwater transport of radionuclides introduced into the subsurface by the Rulison nuclear test. This assessment strives to be as accurate as possible, but the lack of data requires that significant assumptions be made about some critical parameters. As a consequence of these limitations, the results of this modeling are meant to serve merely as a tool to guide further discussion and investigation, not as a definitive assessment of radionuclide migration at the Rulison site. The analysis relies solely on unclassified data available to the general public. Although this may increase the uncertainty of the source term data, and result in the lack of transport calculations for certain radionuclides introduced by the Rulison detonation, these issues can be investigated more thoroughly, and with much greater accuracy, after the acquisition of further data regarding contaminant transport at the site. Measured values were used wherever possible, but given the lack of data, calculations were performed for ranges of certain parameters. The assessment can be made more realistic with the acquisition of additional site data.

\section{METHODOLOGY}

A screening tool approach outlined in Daniels et al. (1993), Andricevic et al. (1994), Cvetkovic et al. (1992), and Andricevic and Cvetkovic (1996) was used to model radionuclide transport from the Rulison site. The employed modeling approach incorporates real physical phenomena, such as instantaneous and/or slow release from the source, advection, dispersion, sorption, mass transfer, and possible uncertainty in the model parameters. The output is the expected concentration profile as a function of time (e.g., concentration breakthrough curves) at the compliance point downgradient from the source, as well as the uncertainty around the expected concentration resulting from the natural hydrogeologic heterogeneity, in general, and from the spatially variable groundwater velocity, in particular. 


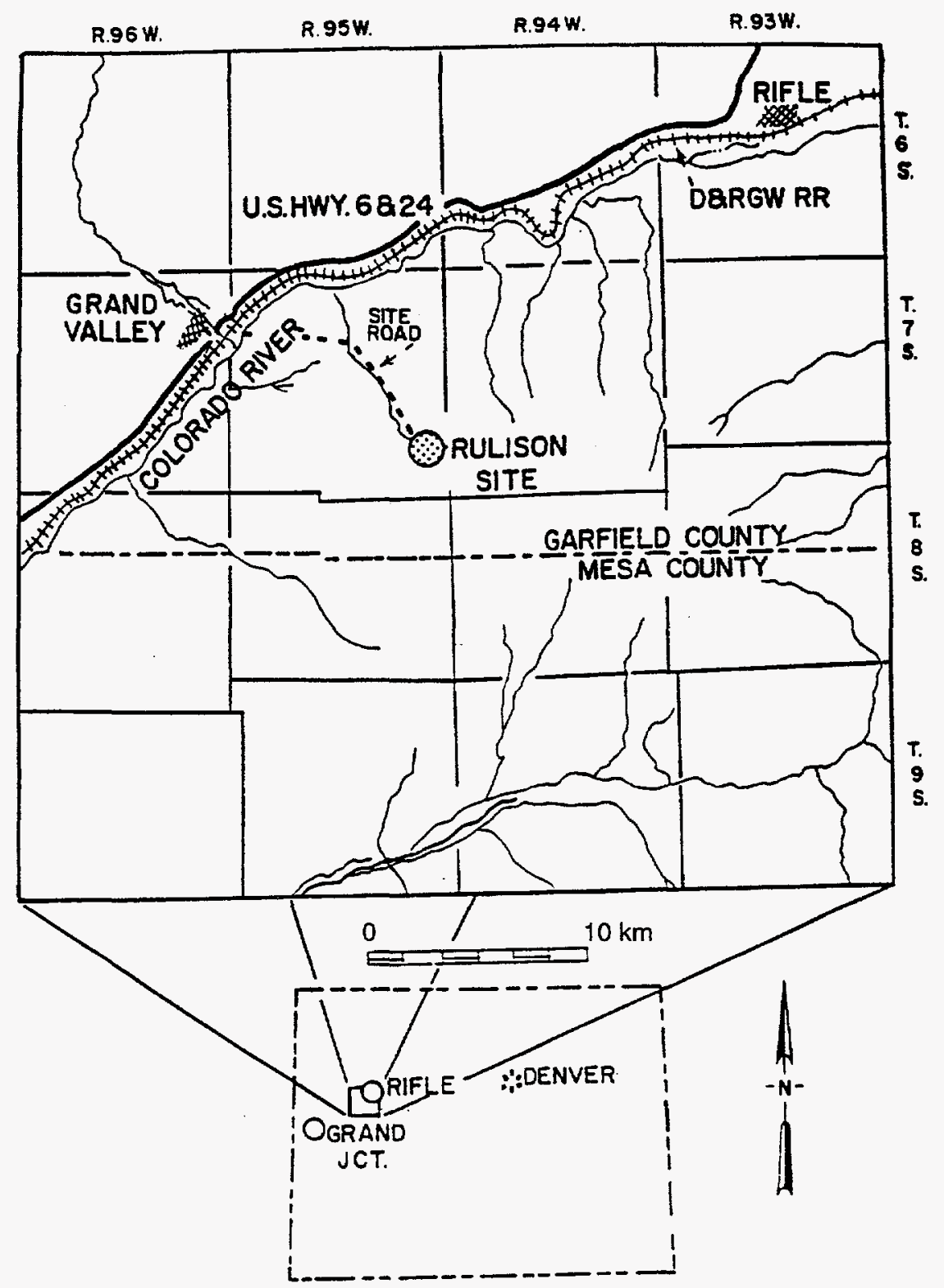

Figure 1. Rulison site location map (from DOE, 1984).

The solute flux method is described in detail by Andricevic and Cvetkovic (1996), while important elements of the approach can also be found in Daniels et al. (1993) and Andricevic et al. (1994). The following summary is derived from these sources, but the reader is directed to these references for a detailed treatment of the method.

The contaminant migration process is described in the solute flux method through the Lagrangian concept of motion following a particle on the Darcy scale. In the absence of direct information on groundwater velocities near Rulison, the mean velocity, $\bar{U}$, is calculated using Darcy's law: 


$$
\overline{\mathrm{U}}=\frac{\overline{\mathrm{K}} \overline{\mathrm{J}}}{\overline{\mathbf{n}}_{\mathrm{c}}}
$$

where $\bar{K}$ is the mean hydraulic conductivity, $\bar{J}$ is the mean hydraulic gradient, and $\bar{n}_{e}$ is the mean effective porosity. Hydrogeologic parameters such as $K$ and $n_{e}$ can be highly variable as a result of geologic heterogeneity. Numerous studies of the variability of hydraulic conductivity have concluded that conductivity is generally log-normally distributed (Freeze and Cherry, 1979; Hoeksema and Kitanidis, 1985). Thus, the natural logarithms of hydraulic conductivity data can be described by a normal distribution with a mean $\mu_{\ln K}$ and variance $\sigma^{2} \ln K$. The variance represents the variability of $K$ about its mean, and may range from near zero for homogeneous deposits to five, or higher, for extremely variable porous media (Hoeksema and Kitanidis, 1985). Because it is distributed in space, $K$ usually has some degree of spatial correlation. The negative exponential function is often used to describe the $K$ correlation structure because it is found to correspond to $\log$ $K$ data and is easy to use. The correlation length of $K, \lambda$, represents the distance beyond which data points show weak correlation. The higher the value of $\lambda$, the greater the spatial continuity of $K$. When the log-normal distribution and the negative exponential covariance function are assumed, the heterogeneous, isotropic hydraulic conductivity field can be statistically characterized by three parameters: $\mu_{\ln K}, \sigma^{2} \ln K$, and $\lambda$.

If the parameters on the right-hand side of the Darcy equation are log-normally distributed, then so is $\bar{U}$ and the estimate of the mean velocity is $\mu_{\ln U}=\mu_{\ln K}+\mu_{\ln J}-\mu_{\ln n e}$. The variance of the estimated mean $U, \sigma^{2} \ln U$, can be calculated as the sum of the variances of the other parameters, if sufficient data are available. The estimation error in $U, \sigma^{2} \ln U$, represents the magnitude of uncertainty in the estimate of $U$ contributed by the estimation errors of $K, J$, and $n_{e}$. The magnitude of the uncertainty in the mean velocity, $\sigma^{2} \ln U$, depends on the number of measurements used to estimate the parameters in the Darcy equation. In the case of independent measurements, $\sigma^{2} \ln U=$ $\sigma^{2} \ln U / N$, where $\sigma^{2} \ln U$ is the variance in the velocity field and $N$ is the number of measurements. For spatially correlated measurements, $\sigma^{2} \ln U$ is scaled by $N^{-1}[1+\bar{Q}(N-1)]$, where $\bar{\varrho}$ is an averaged spatial correlation between data points.

The solute flux method evaluates movement of a solute from the source to a plane perpendicular to the direction of flow. Aquifer heterogeneity is included and represented by the variance of $\log$-hydraulic conductivity, $\sigma^{2}$ lnK , and the hydraulic conductivity integral scale, $\lambda$. The combination of the spatial variability of aquifer properties and the uncertainty in the estimates of these properties causes the solute flux to be a random function described by a probability density function (PDF). The mean and variance of the solute flux are converted to the flux-averaged concentration needed for risk calculations by dividing by the groundwater flux, $Q$. The first two moments of the flux-averaged concentration are important in determining the total risk level. The larger the magnitude of variance in the flux-averaged concentrations, the larger the maximum potential risk.

\section{HYDROGEOLOGIC SETTING}

The geology and hydrogeology of the Rulison site are described by many authors, including Hurr et al. (1969), Nork (1969), Voegeli (1969), Larson and Beetem (1970), Nork and Fenske 
(1970), Reynolds et al. (1970), Voegeli and West (1970), Voegeli and Claassen (1971a), Voegeli and Claassen (1971b), and DOE (1984).

The Rulison event was conducted at a depth of $2,568 \mathrm{~m}$ below ground surface, within the Mesaverde Formation, a Cretaceous body of shale and sandstone (Figure 2). The Mesaverde was deposited in several near-shore depositional environments, including coastal swamp, floodplain, and marine conditions. As a result, sandstone occurs in lenticular form, and these lenses are not continuous. Aquifers in the Rulison area are generally limited to alluvium and terrace deposits, as the underlying formations are typically impermeable, and produce little water, if any (Reynolds $e t$ al., 1970). Nork and Fenske (1970) suggest that groundwater in the Mesaverde may be immobile. An inventory of wells and springs in the surrounding area indicated that only one well produced any significant amount of water from bedrock; this well is reported to be $233 \mathrm{~m}$ deep (completed in the Green River Formation), over 2,300 $\mathrm{m}$ above the shot point (Voegeli and West, 1970). Testing in well R-EX (Figure 3 ) indicated that no water was produced from any formation, although the investigation focused primarily below 1,828 m (Voegeli, 1969; Reynolds et al., 1970).

Due to the fact that no water was obtained during testing, no site-specific information is available regarding hydrogeologic parameters such as transmissivity or groundwater velocity for any formation at the Rulison site.

\section{RELEASE SCENARIO}

There are two potential sources for groundwater contamination by radionuclides at the Rulison site: surface contamination from site activities (e.g., drillback and flaring operations), and subsurface contamination resulting from the radionuclides produced by the shot.

Any tritium on the land surface could possibly migrate through the vadose zone to reach shallow groundwater contained in surficial alluvium. A total of $2.824 \times 10^{15} \mathrm{pCi}$ of tritium (Colorado Dept. of Health, 1980) were released to the atmosphere during four gas flaring operations in 1970 and 1971. Monitoring conducted during the flaring suggests that radionuclides were dispersed by winds over an area covering many square kilometers. For example, tritium concentrations in air were well above background at the old control point pad, $3.8 \mathrm{~km}$ from the flare stack (Boysen, 1976). The site cleanup guideline for tritium in soil moisture was $3.0 \times 10^{7} \mathrm{pCi} / \mathrm{L}$, and the few samples out of the 559 collected that exceeded that guideline (the highest being $4.7 \mathrm{x}$ $10^{7} \mathrm{pCi} / \mathrm{L}$ ) were associated with known locations of spills (Eberline Instrument Corporation, 1977). During a site cleanup operation in 1976, roughly $227 \mathrm{~L}$ of water with a tritium concentration of approximately $2.3 \times 10^{8} \mathrm{pCi} / \mathrm{L}$ were spilled in the vicinity of surface ground zero (SGZ), but decontamination operations (consisting mainly of removing contaminated soil from the site for disposal in Beatty, Nevada) appear to have been successful. Two other minor spills at the site occurred in 1971 and 1972, and sampling of soil water from these areas during the final cleanup operation in 1976 found that decay and dilution had reduced contamination at the spill sites to negligible levels (Eberline Instrument Corporation, 1977).

The fate of tritium in the soil water is to either migrate downward to the shallow water table, or run off into local drainages. Seven shallow wells drilled at the Rulison site in 1995 encountered water between two and $12 \mathrm{~m}$ below ground surface (DOE, 1996). Hydraulic head decreases from 


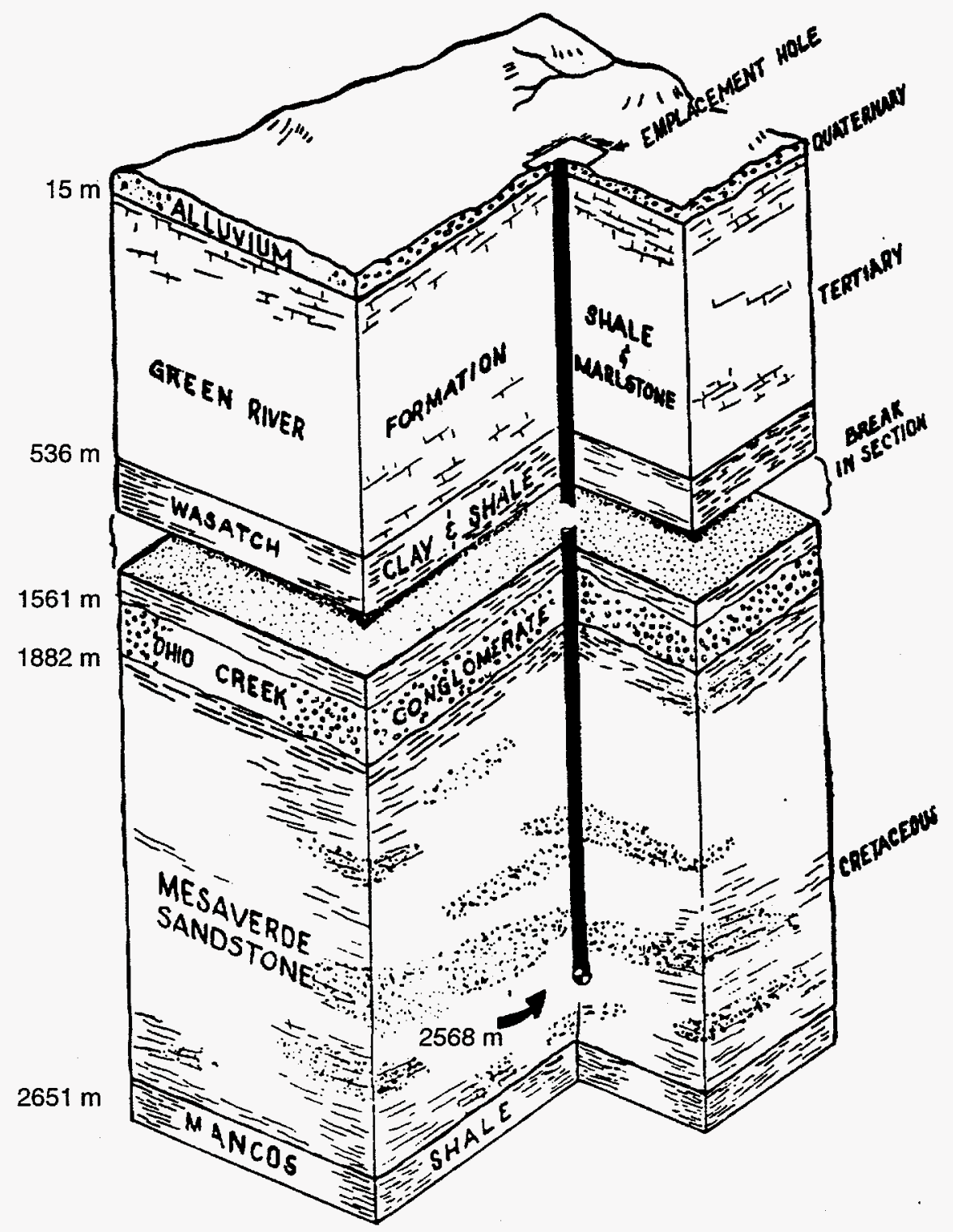

Figure 2. Generalized geologic cross section at the Rulison emplacement hole (from DOE, 1984).

the flaring area downhill to a pond located to the northwest and toward a minor drainage southwest of the flare stack. The presence of a spring and wetland areas to the northwest of the flare stack suggest that discharge from the shallow system may occur locally by evapotranspiration. Transit time through the unsaturated zone will allow radioactive decay, and mixing either in the water table or with surface water will provide dilution, further reducing tritium concentrations. Without any data on the hydraulic properties of the alluvium or interaction between the shallow system and surface water, no additional analysis of the near-surface tritium source is possible.

Approximately six days after the nuclear test took place, gas pressure was measured at the top of the emplacement well (R-E), which was planned to be used as the cavity re-entry well. Although the gas causing this pressure was not sampled at that time, it was thought to have the potential to 


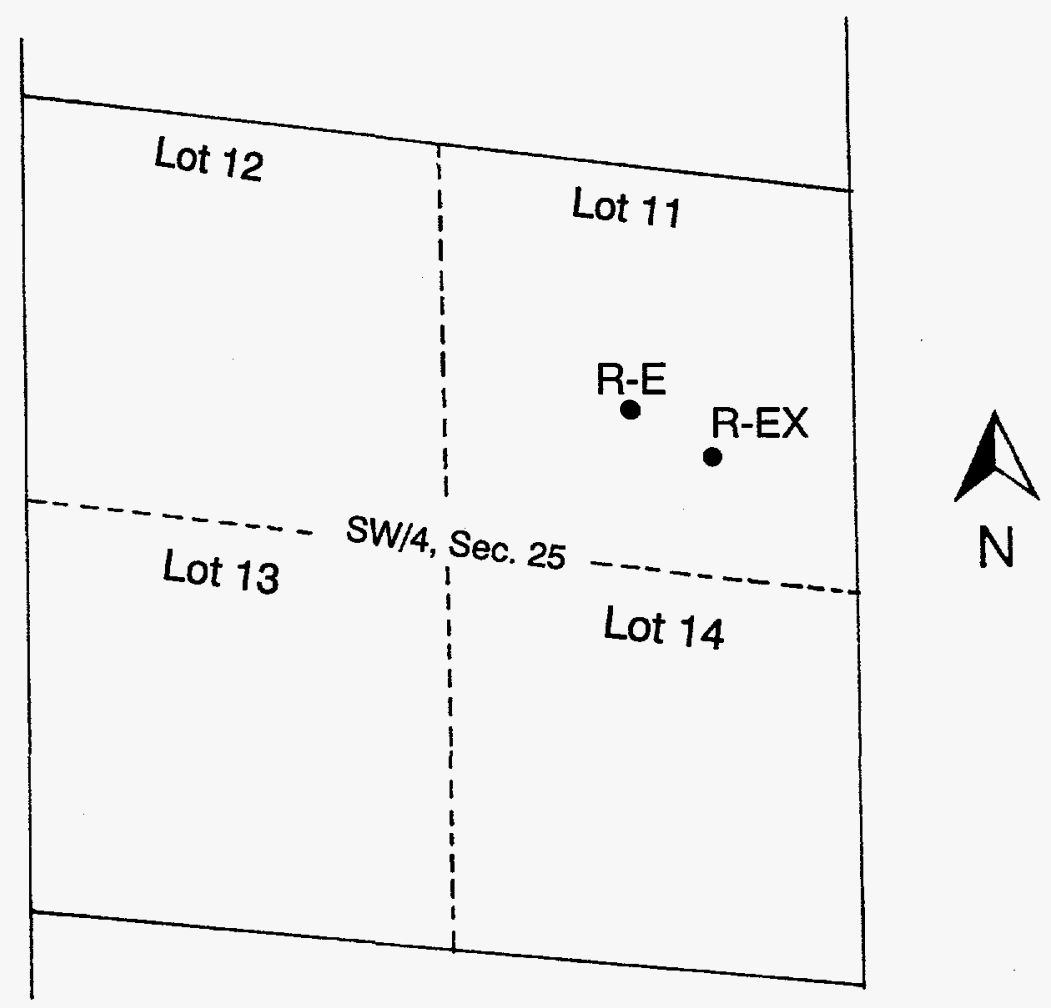

Figure 3. Locations of wells R-E and R-EX in SW/4, section 25 (after Reynolds et al., 1970).

contain radionuclides. To prevent the release of this gas to the atmosphere, cavity re-entry was conducted through another well (R-EX) (Reynolds, 1971). At an unspecified time "several months" after the test, a sample of the gas was withdrawn from the wellhead for radiochemical analysis. Radioactivity found in the sample was determined to have originated from the nuclear explosion, but neither the nuclides present nor their concentrations are given (U.S. Atomic Energy Commission, 1972). Because well R-E was intended for use as both the device emplacement hole and the cavity re-entry hole, the stemming material emplaced prior to the shot consisted only of sand and gravel along with bentonite plugs, so as to facilitate re-entry activities (Reynolds et al., 1970). As this stemming was deemed inadequate to permanently seal the well, site cleanup operations in 1976 included the removal of the stemming material, and the permanent plugging of the well. Radiation monitoring conducted during this operation detected "no radioactive contaminant above natural background" in the stemming material (Eberline Instrument Corporation, 1977), suggesting that any radionuclides which were transported up the well bore after the test were short-lived enough to have decayed below detection limits by the time the cleanup operation was conducted.

Migration of gas through the emplacement well annulus between the outer casing and the borehole wall has been proposed as a worst-case scenario at another gas stimulation test, Project Rio Blanco (U.S. Atomic Energy Commission, 1972). This scenario is considered highly unlikely at both Rio Blanco and Rulison, as it requires continuous fractures to be formed through thousands of meters of cement. In addition, the two wells drilled for Project Rulison were plugged after the ground motion caused by the nuclear test (U.S. Energy Research and Development Administration, 1977), 
further reducing the probability that they could act as conduits for the flow of radionuclides from the cavity toward the surface.

Formation pressures measured at the Rulison site indicate that a zone of low pressure is present above the detonation point ( $2568 \mathrm{~m}$ below land surface) (Table 1). Because the pressure was monitored only in a limited number of sections of the formation, the vertical extent of this low-pressure zone is unknown, but presumably any radionuclides moving upward from the cavity would be drawn out into this low-pressure zone before moving more than $400 \mathrm{~m}$ upward through the formation or annular cracks. The low-pressure zone thus eliminates the possibility of migration to a formation overlying the Mesaverde (Nork and Fenske, 1970). Given these facts, it appears that the migration of radionuclides away from the cavity is likely limited to movement through the formation in which the device was emplaced.

TABLE 1. WELL SHUT-IN PRESSURES AT SELECTED DEPTHS IN THE MESAVERDE FORMATION (from Nork and Fenske, 1970)

\begin{tabular}{cc}
\hline Depth $(\mathrm{m})$ & Shut-in Pressure (MPa) \\
\hline $2154-2158$ & $2.1 \times 10^{1}$ \\
$2193-2194$ & $2.0 \times 10^{1}$ \\
$2229-2231$ & $1.6 \times 10^{1}$ \\
2573 & $2.0 \times 10^{1}$ \\
\hline
\end{tabular}

\section{DATA}

The specific conceptual model evaluated in this exposure assessment is that of groundwater flow transporting radionuclides from the Rulison test point through the Mesaverde Formation to hypothetical receptor locations downgradient. By virtue of describing the solute flux through the Lagrangian concept of motion (following a particle on the Darcy scale), the analytical solution is actually independent of the transport medium, relying simply on the assigned transport properties. The only assumption required is that the particle trajectory not deviate significantly from the mean flow direction. This assumption is imbedded in the first-order approximation used to derive the arrival time moments of the moving plume (see Dagan et al., 1992).

The method allows for matrix diffusion, a potentially important transport process by which solutes are removed from high velocity fracture flowpaths into adjoining matrix blocks. Within the matrix, where velocities are much lower than those in fractures, radioactive decay acts as an effective natural remediating process. In the absence of knowledge about the importance of fracture flow within the Mesaverde Formation, and given the lack of data on matrix diffusion at the site, the process was not considered for this report. Because matrix diffusion can significantly reduce radionuclide concentrations, neglecting it will result in conservative model output values.

The parameters used for the transport calculations are discussed in detail below. In some cases, lack of data requires that significant assumptions be made regarding the appropriate input values. Parametric uncertainty in all of the hydraulic properties can be included through uncertainty in the estimate of the mean velocity, but because data were estimated, sensitivity analyses were performed on parameter ranges instead. 


\section{Source Terms}

The source term used for tritium is $1.0 \times 10^{16} \mathrm{pCi}$, described by Stosur (1977) and Nork and Fenske (1970) as the total amount of device-produced tritium present after the test. Nork and Fenske (1970) list the masses of over 20 other radionuclides that would be present in the cavity 180 days after the test (Table 2); these masses were used as the source terms for each radionuclide listed. Smith et al. (1995) discuss several factors that typically cause hydrologic source terms (the amount of radionuclides available for groundwater transport) to be smaller than radiologic source terms (the total amount of radionuclides produced from a test), many of which apply to Rulison. Using the total radiologic source term is an overestimation of the possible hydrologic source term to the Mesaverde, because it is known that significant amounts of radioactivity remain essentially immobile in the cavity and chimney after a nuclear test. Some radionuclides are unable to migrate from the cavity created by a nuclear blast because they are entrapped in the melt glass formed at the bottom of the cavity. In addition, production testing for natural gas removed portions of the gaseous radionuclides from the cavity. Boysen (1976) describes ${ }^{3} \mathrm{H}$ and ${ }^{85} \mathrm{Kr}$ concentrations as high as $1.2 \times 10^{5}$ and 1.9 $\mathrm{x} 10^{5} \mathrm{pCi} / \mathrm{L}$, respectively, in natural gas produced from the Rulison cavity during a flaring operation. The Colorado Department of Health (1982) states that total surface venting during flaring operations was $2.824 \times 10^{15} \mathrm{pCi}$ for ${ }^{3} \mathrm{H}$, and $1.064 \times 10^{15} \mathrm{pCi}$ for ${ }^{85} \mathrm{Kr}$. The amount (if any) of unburned nuclear fuel (including isotopes of $\mathrm{U}, \mathrm{Pu}$, and $\mathrm{H}$ ) remains classified. Given the purpose of this modeling as a planning tool, and the importance of public access to achieving that purpose, no classified data are included in the analysis. This results in a possible underestimation of nuclides included in unburned fuel, and an uncertainty in the activation and fission products that can be reduced in future transport calculations.

TABLE 2. RADIONUCLIDES PRODUCED BY THE RULISON NUCLEAR TEST (from Nork and Fenske, 1970). Activity values represent those present $180 \mathrm{~d}$ after the shot. Values followed by asterisks represent the high end of a range given by Nork and Fenske (1970).

\begin{tabular}{lccc}
\hline Nuclide & Half Life $(\mathrm{yr})$ & Initial Activity (pCi) & Activity in 1996(pCi) \\
\hline${ }^{3} \mathrm{H}$ & $1.23 \times 10^{1}$ & $1.00 \times 10^{16 *}$ & $2.18 \times 10^{15}$ \\
${ }^{14} \mathrm{C}$ & $5.77 \times 10^{3}$ & $1.00 \times 10^{11 *}$ & $9.97 \times 10^{10}$ \\
${ }^{37} \mathrm{Ar}$ & $9.40 \times 10^{-2}$ & $1.00 \times 10^{14 *}$ & $3.57 \times 10^{-73}$ \\
${ }^{39} \mathrm{Ar}$ & $2.60 \times 10^{2}$ & $2.00 \times 10^{13 *}$ & $9.74 \times 10^{12}$ \\
${ }^{85} \mathrm{Kr}$ & $1.08 \times 10^{1}$ & $9.60 \times 10^{14}$ & $1.70 \times 10^{14}$ \\
${ }^{89} \mathrm{Sr}$ & $1.39 \times 10^{-1}$ & $9.10 \times 10^{16}$ & $3.15 \times 10^{-42}$ \\
${ }^{90} \mathrm{Sr}$ & $2.88 \times 10^{1}$ & $5.90 \times 10^{15}$ & $3.08 \times 10^{15}$ \\
${ }^{91} \mathrm{Y}$ & $1.62 \times 10^{-1}$ & $1.01 \times 10^{17}$ & $6.97 \times 10^{-34}$ \\
${ }^{95} \mathrm{Zr}$ & $1.78 \times 10^{-1}$ & $1.82 \times 10^{17}$ & $4.05 \times 10^{-29}$ \\
${ }^{95} \mathrm{Nb}$ & $9.59 \times 10^{-2}$ & $3.20 \times 10^{17}$ & $5.89 \times 10^{-68}$ \\
${ }^{103} \mathrm{Rh}$ & $1.08 \times 10^{-4}$ & $4.10 \times 10^{16}$ & $<10^{-75}$ \\
${ }^{103} \mathrm{Ru}$ & $1.10 \times 10^{-1}$ & $4.10 \times 10^{16}$ & $5.49 \times 10^{-58}$ \\
${ }^{106} \mathrm{Rh}$ & $9.51 \times 10^{-7}$ & $1.52 \times 10^{17}$ & $<10^{-75}$ \\
${ }^{106} \mathrm{Ru}$ & $1.00 \times 10^{0}$ & $1.52 \times 10^{17}$ & $1.14 \times 10^{9}$ \\
${ }^{131} \mathrm{I}$ & $2.21 \times 10^{-2}$ & $1.13 \times 10^{12}$ & $<10^{-75}$ \\
${ }^{133 \mathrm{Xe}}$ & $1.44 \times 10^{-2}$ & $8.60 \times 10^{8}$ & $<10^{-75}$ \\
${ }^{137} \mathrm{Ba}$ & $4.95 \times 10^{-6}$ & $6.90 \times 10^{15}$ & $<10^{-75}$ \\
${ }^{137} \mathrm{Cs}$ & $3.00 \times 10^{1}$ & $7.50 \times 10^{15}$ & $4.02 \times 10^{15}$ \\
\hline
\end{tabular}


TABLE 2. RADIONUCLIDES PRODUCED BY THE RULISON NUCLEAR TEST (from Nork and Fenske, 1970). Activity values represent those present $180 \mathrm{~d}$ after the shot. Values followed by asterisks represent the high end of a range given by Nork and Fenske (1970) (Continued).

\begin{tabular}{lccc}
\hline Nuclide & Half Life (yr) & Initial Activity (pCi) & Activity in 1996 (pCi) \\
${ }^{140} \mathrm{Ba}$ & $3.51 \times 10^{-2}$ & $3.40 \times 10^{14}$ & $<10^{-75}$ \\
${ }^{140} \mathrm{La}$ & $4.57 \times 10^{-3}$ & $4.00 \times 10^{14}$ & $<10^{-75}$ \\
${ }^{141} \mathrm{Ce}$ & $8.90 \times 10^{-2}$ & $5.2 \times 10^{16}$ & $2.58 \times 10^{-75}$ \\
${ }^{143} \mathrm{Pr}$ & $3.75 \times 10^{-2}$ & $6.3 \times 10^{14}$ & $<10^{-75}$ \\
${ }^{144} \mathrm{Ce}$ & $7.81 \times 10^{-1}$ & $1.47 \times 10^{17}$ & $5.79 \times 10^{6}$ \\
${ }^{144} \mathrm{Pr}$ & $3.29 \times 10^{-5}$ & $1.47 \times 10^{17}$ & $<10^{-75}$ \\
${ }^{147} \mathrm{Pm}$ & $2.60 \times 10^{0}$ & $2.80 \times 10^{16}$ & $2.10 \times 10^{13}$ \\
\hline
\end{tabular}

\section{Attenuation Factors}

As discussed by Smith et al. (1995), there are a number of factors that complicate the release function of various radionuclides from an underground test: heterogeneous spatial distribution (in melt matrix, on surfaces, etc.), solubility, sorption, and colloid formation. Smith et al. (1995) emphasize the importance of time in evaluating the transition from radiologic to hydrologic source term because the relative importance of the radionuclides changes during decay. All of these factors are essentially unknown for the Rulison test.

Although distribution coefficients were not measured for rocks from the Rulison site, Nork and Fenske (1970) summarize distribution coefficients measured for strontium and cesium using rocks from other nuclear test areas, and describe rocks from the Gasbuggy site as being similar to those present at the Rulison site. Based on that similarity, $K_{d}$ values reported by Sokol (1970) for the Gasbuggy site were assumed to be representative of those at the Rulison site. The lowest $K_{d}$ values measured for $\mathrm{Sr}$ and $\mathrm{Cs}$ in contact with the Ojo Alamo Sandstone were used: $1.13 \mathrm{~mL} / \mathrm{g}$ for Sr and $139 \mathrm{~mL} / \mathrm{g}$ for Cs (Sokol, 1970). The $K_{d}$ used for the transport calculations is a distribution coefficient made dimensionless by multiplying by the ratio of the bulk density and the effective porosity. Using a porosity of 0.087 , interpreted by Reynolds et al. (1970) from core tests and well log data, and a bulk density of $2.35 \mathrm{~g} / \mathrm{cm}^{3}$, interpreted from density logs (Austral Oil Co. and CER Geonuclear, $1966)$, the dimensionless $K_{d}$ values $\left(\bar{K}_{d}\right)$ applied to Rulison were $\bar{K}_{d}=31$ for $\mathrm{Sr}$ and $\bar{K}_{d}=3.8 \times 10^{3}$ for Cs.

$K_{d}$ is strongly dependent on mineralogy and the geochemical environment and the lack of site-specific data results in great uncertainty in the values used here. This uncertainty is addressed by evaluating transport of $\mathrm{Sr}$ and $\mathrm{Cs}$ without sorption processes. In the absence of sorption data for other radionuclides, their transport was modeled as being unretarded. Although this assumption is most likely valid in the case of ${ }^{3} \mathrm{H}$, it should be considered highly conservative for most, if not all the other radionuclides listed in Table 2.

\section{Discharge Mixing Area}

The discharge mixing area is the cross-sectional size of the contaminant plume as it passes the control plane. It is used in conjunction with the average velocity and porosity to estimate the volume of groundwater which contains radionuclides. 
For each model run, the discharge mixing area was calculated by estimating the transverse width of the resultant plume at the required distance, and multiplying this value by the thickness of the Mesaverde assumed to be transporting radionuclides. It was assumed that radionuclides were introduced into only that thickness of the Mesaverde fractured by the blast, and that all subsequent transport was confined to this lateral plane only. The mean fracture diameter of $296 \mathrm{~m}$ (Nork and Fenske, 1970) was used as the thickness of the Mesaverde in which the radionuclides from the shot were released, and through which migration occurred.

The initial width of the plume was assumed to be $296 \mathrm{~m}$, equivalent to the maximum estimated fracture diameter (Nork and Fenske, 1970), and was expanded downgradient to account for transverse dispersion. To calculate the width of the plume at any given point downgradient, the formula

$$
\mathrm{W}=\mathrm{w}_{\mathrm{o}}+2 \sqrt{2 \mathrm{D}_{\mathrm{t}} \mathrm{t}}
$$

was used, where $W$ is equal to the downstream plume width, $w_{o}$ is the initial transverse source width (296 m), $D_{t}$ is the transverse hydrodynamic dispersion coefficient of the aquifer (assumed to be 1

$\mathrm{m}^{2} / \mathrm{yr}$ ), and $t$ is the time of transport. The two terms in this equation represent the initial source width and the amount of transverse dispersion and diffusion that occurs during transport to the control plane.

Because the source size used here $(296 \mathrm{~m})$ is larger than the correlation scale $(28.6 \mathrm{~m}$, as discussed below), assuming a point-source would eliminate any diffusion on a scale smaller than that of the correlation scale, resulting in increased concentration values because the area in which the radionuclide mass is contained is kept artificially small. For this reason, a version of the solute flux model which incorporates source size into its calculations (Cvetkovic et al., 1992) was used to perform all the modeling described in this report. Other offsite nuclear test area hydrologic assessments (Earman et al., 1996a, 1996b) were able to use the point-source model because the source size was considered small relative to the correlation scale. It should be emphasized that neither the source size nor the correlation scale are known values; they are simply estimated, based on the cavity diameter and the general relationship of correlation scale to transport distance, respectively.

The value for $D_{t}$ was estimated from aquifer characteristics, and due to this fact, a sensitivity analysis was performed to determine how changes in the transverse hydrodynamic dispersion coefficient would alter model results for tritium transport. Values of $0.1 \mathrm{~m}^{2} / \mathrm{yr}$ and $10 \mathrm{~m}^{2} / \mathrm{yr}$ were used in the sensitivity analysis.

\section{Distance to Control Plane}

A monument at SGZ bears a plaque prohibiting any drilling or subsurface excavation below a depth of $1,829 \mathrm{~m}$ "within lot 11, NE 1/4, SW 1/4, of Section 25, Township 7 South, Range 95 West, 6th Principal Meridian, Garfield County, Colorado" (U.S. Energy Research and Development Agency, 1977) (Figure 3). This description corresponds with the subsurface rights held by the U.S. government (U.S. Atomic Energy Commission, 1973). Although there is no definitive direction of groundwater flow at the site, Reynolds et al. (1970) describe the Upper Cretaceous formations in the area (of which the Mesaverde is one) as having a slope of $2.84 \times 10^{-2}$ to the northeast. Nork and 
Fenske (1970) suggest a dip of $3.5 \times 10^{-2}$ to the north, and state that groundwater flow at the site is expected to be in the direction of dip. For this report, the dip direction given by Reynolds et al. (1970) was assumed to be correct, and, in the absence of any other information regarding the hydraulic gradient, their regional dip value was used. According to Reynolds et al. (1970), the distance from SGZ to the northeastern corner of the drilling exclusion boundary is $286 \mathrm{~m}$.

\section{Correlation Scale}

The correlation scale (also known as the integral scale) is the distance beyond which two measurements of hydraulic conductivity tend to exhibit a weak correlation. A large value suggests a system with a high degree of spatial correlation, and has the net effect of extending the path length of higher conductivity conduits. Hoeksema and Kitanidis (1985) report a range for correlation scales of transmissivity in consolidated rock aquifers of 1,400 to $44,700 \mathrm{~m}$ (mean of $17,400 \mathrm{~m}$ ), but these values refer to aquifer-wide properties, and it has been shown that the correlation scale increases systematically with increasing overall scale. Analysis of correlation and overall scales for a number of well-characterized sites revealed a predictable relationship of the correlation scales being approximately ten percent of the overall scale (Gelhar, 1993).

The correlation scale used was $28.6 \mathrm{~m}$, one-tenth of the distance to the control plane. Owing to the uncertainty in this value, a sensitivity analysis was performed to determine how changes in the correlation scale would alter the model results for tritium transport. Values of two and five times the base-case value (57.2 and $142 \mathrm{~m}$ ) were used.

\section{Effective Porosity}

An effective porosity of 8.7 percent (0.087) was assumed for the Mesaverde, based on the average of three values calculated from core tests and well log data (Reynolds et al., 1970). It should be noted that this value is reported to represent total porosity, as opposed to effective porosity. In spite of this fact, the value of 0.087 was used, because no value for effective porosity is reported in the available literature. The uncertainty in effective porosity is incorporated in the overall uncertainty in mean velocity, discussed in the following section.

\section{Mean Groundwater Velocity}

The mean groundwater velocity used in the transport calculations was $1.1 \mathrm{~m} / \mathrm{yr}$. The mean velocity was calculated from values for aquifer hydraulic conductivity and effective porosity, in conjunction with the regional hydraulic gradient. The dearth of hydrogeologic data from the Rulison site made the selection of the parameters from which this value was calculated a difficult task.

As previously described, the lack of water in the Mesaverde prevented any pumping tests to determine aquifer properties such as transmissivity. Reynolds et al. (1970) provide two values for the permeability of the Mesaverde, 0.5 and 11 millidarcies. Permeability values can be converted to hydraulic conductivity values, but there are several underlying assumptions to this process, most notably that the pore spaces in question are completely saturated with water. The Mesaverde is estimated to be only 38 to 55 percent saturated with water, as gas and a small quantity of oil are present as well (Reynolds et al., 1970). Although the underlying assumptions are obviously not met in this case, in the absence of any values for hydraulic conductivity, it was decided to estimate the 
conductivity values by using the standard conversion formula on the permeability data. The two reported permeability values are thus assumed to be equivalent to hydraulic conductivities of 1.06 $\times 10^{-7}$ and $2.61 \times 10^{-4} \mathrm{~m} / \mathrm{d}$. The latter value was used, contributing to a conservative estimate of groundwater velocity.

An effective porosity of 0.087 (Reynolds et al., 1970) was used in the mean velocity calculation. As described above, this value is reported as representing total porosity, but was used in the absence of any data for effective porosity.

As described previously, no definitive information regarding the hydraulic gradient at the site is given in the available literature, but Nork and Fenske (1970) state that groundwater at the site most likely flows in the direction of regional dip. The value and direction of dip provided by Reynolds et al. (1970) were assumed to represent the hydraulic gradient $\left(2.84 \times 10^{-2}\right)$ and the direction of groundwater flow (northeast) at the site.

The solute flux model includes an estimation error in mean velocity to account for uncertainty in the assigned mean velocity due to uncertainties in mean effective porosity, mean hydraulic conductivity, and mean hydraulic gradient. The lack of data did not allow calculation of these uncertainties at the Rulison site. Instead, a sensitivity analysis for the velocity value was used to examine the effects resulting from an estimation error. It is important to stress that the sensitivity analysis addresses the uncertainty in the mean velocity. The range of velocities in the flow field is incorporated through the spatial variability in hydraulic conductivity and would be expected to be much larger than the uncertainty in the mean.

In addition to the assumed value of $1.1 \mathrm{~m} / \mathrm{yr}$, values of 0.05 and $3.2 \mathrm{~m} / \mathrm{yr}$ were used in the sensitivity analysis for velocity. The lower value was obtained by using the lower of the two permeability values provided by Reynolds et al. (1970) in the velocity equation, while holding all other values constant. Because the value used for effective porosity is actually a total porosity value, as described earlier, and the permeability of the Mesaverde Formation appears to be low for a sandstone body with a porosity of 0.087 , an effective porosity value of three percent (0.03) was assumed, and used (with all other values held constant) to generate the velocity of $3.2 \mathrm{~m} / \mathrm{yr}$.

\section{Spatial Variability in Hydraulic Conductivity}

It is known that hydraulic conductivity varies through space due to geologic variability. The variability in $K$ creates flowpaths with both higher and lower mean velocities than those calculated using the mean $K$, and results in spreading of a contaminant plume along the direction of flow. The spreading is noted at the control plane as early arrivals in advance of the bulk of the contaminant mass, and a "tail" of trailing arrivals behind the bulk of the mass. The early arrivals caused by spatial variability in hydraulic conductivity are particularly important when considering transport of a decaying solute such as tritium because the mass of contaminant decreases with time. A large variance allows more variation in $K$ about the mean value, and thus results in a distribution of velocities that can include much faster flowpaths than the mean. A lower variance restricts the spreading about the mean.

In the absence of any spatially distributed data for hydraulic conductivity at the Rulison site, a value of 0.3 was used for the variance in the natural logarithm of hydraulic conductivity $(\ln K)$. This 
value is the median value for consolidated aquifers, as reported by Hoeksema and Kitanidis (1985). Because of uncertainty in the variance value, a sensitivity analysis was performed to determine how changes in the variance would alter the model results for tritium transport. A value of 0.704 was used; this is the highest value of $\ln K$ cited by Hoeksema and Kitanidis (1985) for a sandstone aquifer.

\section{RESULTS}

Figure 4 shows the results of the instantaneous release to the Mesaverde of the entire mass of tritium from the test, and the transport of this material northeast to the drilling exclusion boundary, a distance of $286 \mathrm{~m}$. It indicates that mean tritium concentration peaks at $162 \mathrm{pCi} / \mathrm{L}$ at the boundary in the year 2130. At the same location, the mean concentration plus two standard deviations peaks at $396 \mathrm{pCi} / \mathrm{L}$. Neither of these values exceeds $20,000 \mathrm{pCi} / \mathrm{L}$, the U.S. Environmental Protection Agency (EPA) human consumption limit for tritium (40 CFR 141.16, 1995).

Transport calculations were performed for all the radionuclides listed in Table 2, with retardation assumed to be occurring only for ${ }^{90} \mathrm{Sr}$ and ${ }^{137} \mathrm{Cs}$. As previously discussed, this is a good approximation in the case of ${ }^{3} \mathrm{H}$, but in most other cases is highly conservative, as many of the remaining radionuclides are typically strongly sorbing. The results of these calculations (Table 3) suggest that no radionuclide would be present at the drilling exclusion boundary at a peak mean concentration or peak mean concentration plus two standard deviations in exceedence of the detection limits required by the EPA.

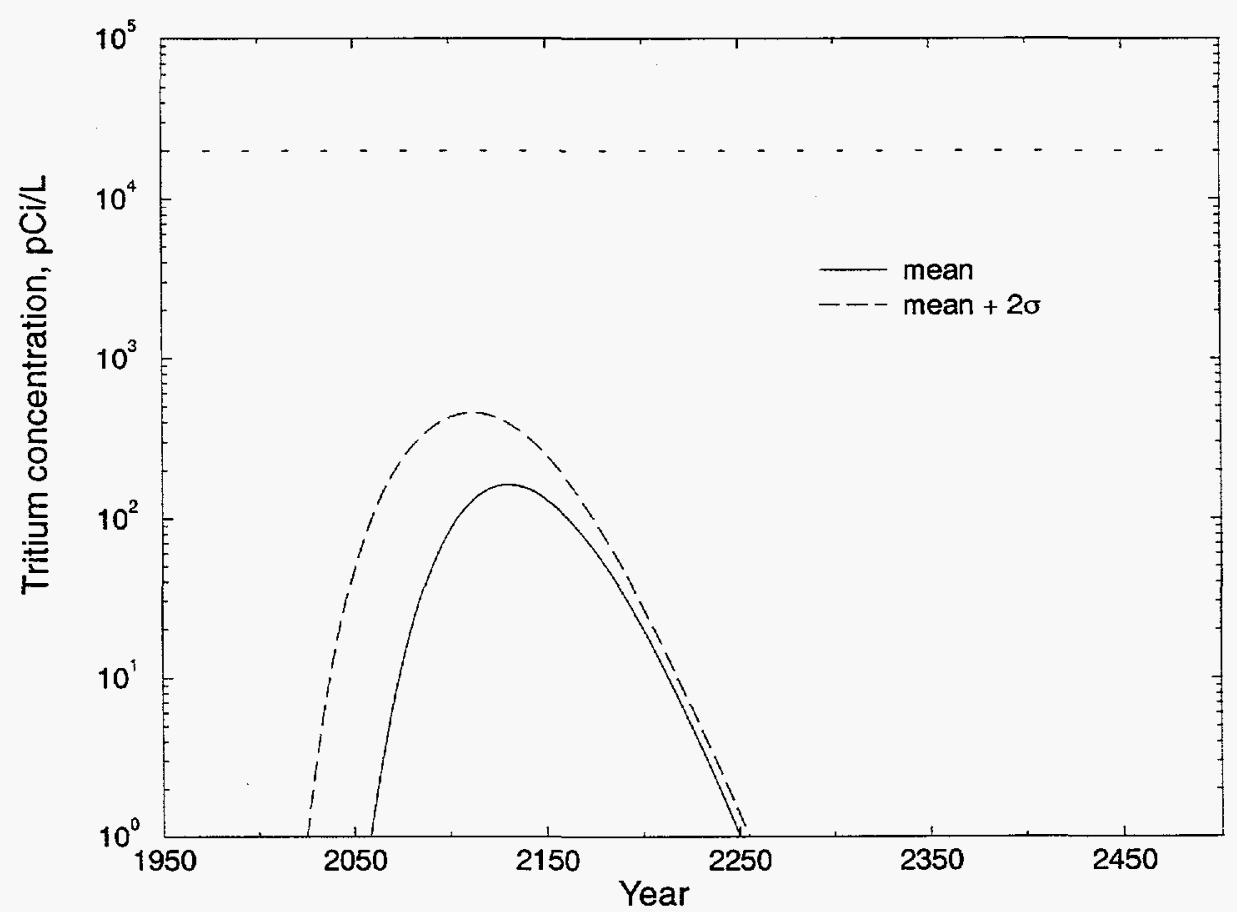

Figure 4. Modeled tritium concentrations at the drilling exclusion boundary resulting from the Rulison test. Dashed line indicates the EPA maximum concentration for human consumption $(20,000$ $\mathrm{pCi} / \mathrm{L})$. 
TABLE 3. RESULTS OF GROUNDWATER TRANSPORT CALCULATIONS FOR RADIONUCLIDES PRODUCED BY THE RULISON TEST. No retardation was assumed for nuclides other than ${ }^{90} \mathrm{Sr}$ and ${ }^{137} \mathrm{Cs}$, though many of them are expected to be strongly sorbing or be in insoluble form. The concentrations presented are the peak values in the mean breakthrough curves at the Rulison drilling exclusion boundary. For reference, nuclide concentrations causing a $4 \mathrm{mrem} / \mathrm{yr}$ dose rate (as per 40 CFR 141.16 (EPA, 1976)) and their required detection limits are also presented.

\begin{tabular}{|c|c|c|c|c|c|}
\hline Nuclide & $\begin{array}{c}\text { Peak Mean } \\
\text { Concentration } \\
\text { at the Boundary } \\
(\mathrm{pCi} / \mathrm{L})\end{array}$ & $\begin{array}{l}\text { Peak Mean } \\
\text { Concentration } \\
\text { Plus } 2 \sigma \\
(\mathrm{pCi} / \mathrm{L})\end{array}$ & $\begin{array}{c}\text { Time of } \\
\text { Arrival of Peak } \\
\text { Mean } \\
\text { Concentration } \\
\text { at Boundary } \\
\text { (yr after 1969) }\end{array}$ & $\begin{array}{c}\text { Concentration } \\
\text { causing } \\
4 \text { mrem/yr } \\
\text { Dose Rate } \\
(\mathrm{pCi} / \mathrm{L})\end{array}$ & $\begin{array}{c}\text { Detection } \\
\text { Limit } \\
\text { required in } \\
40 \mathrm{CFR} \\
141.25 \\
(\mathrm{pCi} / \mathrm{L}) \\
\end{array}$ \\
\hline${ }^{3} \mathrm{H}$ & $1.62 \times 10^{2}$ & $3.96 \times 10^{2}$ & 161 & $2.4 \times 10^{4}$ & $1.0 \times 10^{3}$ \\
\hline${ }^{14} \mathrm{C}$ & $8.36 \times 10^{1}$ & $1.11 \times 10^{2}$ & 242 & $3.0 \times 10^{3}$ & $3.0 \times 10^{2}$ \\
\hline${ }^{39} \mathrm{Ar}$ & $9.09 \times 10^{3}$ & $1.22 \times 10^{4}$ & 236 & NA (Gas) & NA (Gas) \\
\hline${ }^{85} \mathrm{Kr}$ & $4.20 \times 10^{0}$ & $1.42 \times 10^{1}$ & 155 & $6.0 \times 10^{3}$ & $6.0 \times 10^{2}$ \\
\hline${ }^{90} \mathrm{Sr}$ & $1.85 \times 10^{-22}$ & $1.53 \times 10^{-16}$ & 1,500 & $8.0 \times 10^{0}$ & $2.0 \times 10^{0}$ \\
\hline${ }^{106} \mathrm{Ru}$ & $1.06 \times 10^{-19}$ & $3.28 \times 10^{-14}$ & 50 & $3.0 \times 10^{1}$ & $3.0 \times 10^{0}$ \\
\hline${ }^{144} \mathrm{Ce}$ & $1.20 \times 10^{-23}$ & $5.48 \times 10^{-17}$ & 43 & $3.0 \times 10^{1}$ & $3.0 \times 10^{0}$ \\
\hline${ }^{147} \mathrm{Pm}$ & $1.69 \times 10^{-8}$ & $2.54 \times 10^{-6}$ & 86 & $6.0 \times 10^{2}$ & $6.0 \times 10^{1}$ \\
\hline${ }^{37} \mathrm{Ar}$ & $<\mathrm{CL}$ & $<\mathrm{CL}$ & NA & NA (Gas) & NA (Gas) \\
\hline${ }^{89} \mathrm{Sr}$ & $<\mathrm{CL}$ & $<\mathrm{CL}$ & NA & $8.0 \times 10^{1}$ & $1.0 \times 10^{1}$ \\
\hline${ }^{91} \mathrm{Y}$ & $<\mathrm{CL}$ & $<\mathrm{CL}$ & NA & $9.0 \times 10^{1}$ & $9.0 \times 10^{0}$ \\
\hline${ }^{95} \mathrm{Zr}$ & $<C L$ & $<\mathrm{CL}$ & $\mathrm{NA}$ & $2.0 \times 10^{2}$ & $2.0 \times 10^{1}$ \\
\hline${ }^{95} \mathrm{Nb}$ & $<\mathrm{CL}$ & $<\mathrm{CL}$ & NA & $3.0 \times 10^{2}$ & $3.0 \times 10^{1}$ \\
\hline${ }^{103} \mathrm{Ru}$ & $<\mathrm{CL}$ & $<\mathrm{CL}$ & NA & $2.0 \times 10^{2}$ & $2.0 \times 10^{1}$ \\
\hline${ }^{103} \mathrm{Rh}$ & $<\mathrm{CL}$ & $<\mathrm{CL}$ & NA & $3.0 \times 10^{4}$ & $3.0 \times 10^{3}$ \\
\hline${ }^{106} \mathrm{Rh}$ & $<\mathrm{CL}$ & $<\mathrm{CL}$ & NA & NP & $\mathrm{NP}$ \\
\hline${ }^{131} \mathbf{I}$ & $<\mathrm{CL}$ & $<\mathrm{CL}$ & NA & $3.0 \times 10^{0}$ & $1.0 \times 10^{0}$ \\
\hline${ }^{133} \mathrm{Xe}$ & $<\mathrm{CL}$ & $<\mathrm{CL}$ & NA & NA (Gas) & NA (Gas) \\
\hline${ }^{137} \mathrm{Ba}$ & $<\mathrm{CL}$ & $<\mathrm{CL}$ & NA & NP & NP \\
\hline${ }^{137} \mathrm{Cs}$ & $<\mathrm{CL}$ & $<\mathrm{CL}$ & $\mathrm{NA}$ & $2.0 \times 10^{2}$ & $2.0 \times 10^{1}$ \\
\hline${ }^{140} \mathrm{Ba}$ & $<\mathrm{CL}$ & $<\mathrm{CL}$ & NA & $9.0 \times 10^{1}$ & $9.0 \times 10^{0}$ \\
\hline${ }^{140} \mathrm{La}$ & $<\mathrm{CL}$ & $<\mathrm{CL}$ & $\mathrm{NA}$ & $6.0 \times 10^{1}$ & $6.0 \times 10^{0}$ \\
\hline${ }^{141} \mathrm{Ce}$ & $<\mathrm{CL}$ & $<\mathrm{CL}$ & NA & $3.0 \times 10^{2}$ & $3.0 \times 10^{1}$ \\
\hline${ }^{143} \mathrm{Pr}$ & $<\mathrm{CL}$ & $<\mathrm{CL}$ & NA & $1.0 \times 10^{2}$ & $1.0 \times 10^{1}$ \\
\hline${ }^{144} \mathrm{Pr}$ & $<\mathrm{CL}$ & $<\mathrm{CL}$ & NA & NP & NP \\
\hline
\end{tabular}

$\mathrm{CL}=$ Calculation limit for solute flux model (approximately $10^{-45} \mathrm{pCi} / \mathrm{L}$ )

NA $=$ Not applicable

NA (Gas) = Not applicable, as gas phase dose rates pertain to body immersion rather than ingestion

$\mathrm{NP}=168$ hour data not provided in NBS Handbook 69 (U.S. Department of Commerce, 1963) for calculating EPA maximum contaminant level per 40 CFR 141.16

\section{Sensitivity Analyses}

As discussed earlier, the lack of hydrogeologic data from the Rulison site could cause large discrepancies between model results and reality. To understand the relative importance of 
uncertainty in various model parameters, sensitivity analyses were conducted for the correlation scale of hydraulic conductivity, mean groundwater velocity, the variance of hydraulic conductivity, and the transverse hydrodynamic dispersion coefficient. For these hydraulic parameters, mean tritium concentration $286 \mathrm{~m}$ west of SGZ was computed to see how it differed from the $162 \mathrm{pCi} / \mathrm{L}$ value initially predicted. If these results suggested a peak mean tritium concentration at the section boundary greater than $20,000 \mathrm{pCi} / \mathrm{L}$, additional modeling was conducted to approximate the distance from SGZ at which concentrations would never exceed that value. Sensitivity to $K_{d}$ was also evaluated for ${ }^{90} \mathrm{Sr}$ and ${ }^{137} \mathrm{Cs}$ by evaluating transport in the absence of retardation.

Figure 5 shows the results of the sensitivity analysis for the correlation scale. The original value of $\lambda(28.6 \mathrm{~m})$ was increased by a factor of two and a factor of five, yielding values of 57.2 and 143 $\mathrm{m}$. At $286 \mathrm{~m}$ west of SGZ, increasing values of $\lambda$ cause increases in tritium concentration, with a $\lambda$ of $143 \mathrm{~m}$ producing a peak mean concentration of $1,230 \mathrm{pCi} / \mathrm{L}$, one order of magnitude higher than predicted for $\lambda=28.6 \mathrm{~m}$.

The results of the sensitivity analysis for mean velocity are shown in Figure 6. As discussed earlier, the low permeability value presented by Reynolds et al. (1970) was used to calculate a velocity of $0.05 \mathrm{~m} / \mathrm{yr}$, and an estimated effective porosity value of 0.03 was used to calculate a velocity of $3.2 \mathrm{~m} / \mathrm{yr}$. These values were used in the sensitivity analysis, in addition to the initial value of $1.1 \mathrm{~m} / \mathrm{yr}$. If mean velocity is assumed to be $0.05 \mathrm{~m} / \mathrm{yr}$, mean tritium concentration $286 \mathrm{~m}$ west of SGZ would peak at less than $1.0 \times 10^{-26} \mathrm{pCi} / \mathrm{L}$, a value too low to appear on the graph in Figure 6. This greater-than-twentyfold decrease in velocity produces a twenty-nine order-of-magnitude decrease in concentration. In the case of the high-end velocity, mean tritium concentration peaks at $1.4 \times 10^{5} \mathrm{pCi} / \mathrm{L}$ at the drilling exclusion boundary, and would exceed $20,000 \mathrm{pCi} / \mathrm{L}$ to a distance of approximately $400 \mathrm{~m}$ northeast of SGZ. In this case, a threefold increase in velocity produces a nearly three order of magnitude increase in concentration.

The results of the sensitivity analysis for variance are shown in Figure 7 . The value of 0.704 used in the sensitivity analysis is the highest value for the variance of $\ln K$ in a sandstone aquifer reported by Hoeksema and Kitanidis (1985). Model results based on this variance suggest a peak mean tritium concentration of $1,160 \mathrm{pCi} / \mathrm{L} 286 \mathrm{~m}$ west of $\mathrm{SGZ}$, significantly lower than the concentration guideline. This greater-than-twofold increase in the variance produces a fivefold increase in the predicted concentration value.

Figure 8 shows the results of the sensitivity analysis for the transverse hydrodynamic dispersion coefficient. The value for $D_{t}$ used in this study was estimated from aquifer characteristics, most notably that groundwater is conducted primarily through pore spaces. High values of $D_{t}$ result in a large degree of plume spreading, thus diluting a given mass of radionuclides, while low values of $D_{t}$ minimize plume spreading, concentrating the mass into a smaller area. Values of 0.1 and 10 $\mathrm{m}^{2} / \mathrm{yr}$ were used in the sensitivity analysis, in addition to the original value of $1 \mathrm{~m}^{2} / \mathrm{yr}$. For $D_{t}=0.1$ $\mathrm{m}^{2} / \mathrm{yr}$, model results indicate a peak mean tritium concentration of $197 \mathrm{pCi} / \mathrm{L} 286 \mathrm{~m}$ west of SGZ. For $D_{t}=10 \mathrm{~m}^{2} / \mathrm{yr}$, peak mean concentration at that distance would be $140 \mathrm{pCi} / \mathrm{L}$. In these instances, both tenfold changes in $D_{t}$ produce less than twofold changes in predicted concentrations.

The sensitivity to $K_{d}$ values for ${ }^{90} \mathrm{Sr}$ and ${ }^{137} \mathrm{Cs}$ can be evaluated by considering calculations using no sorption. If no sorption is assumed, the peak mean concentration of ${ }^{90} \mathrm{Sr}$ would pass the 


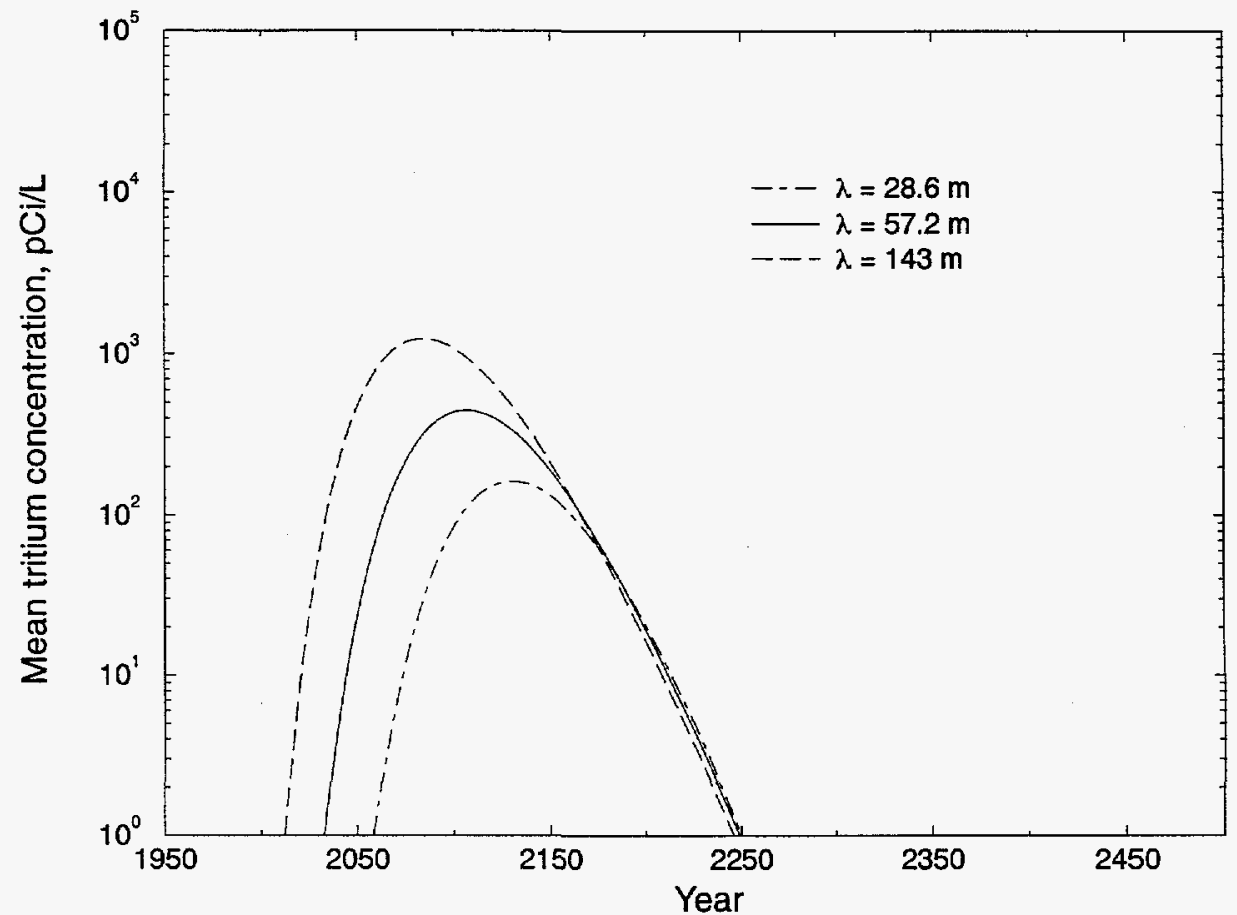

Figure 5. Sensitivity of mean tritium concentration $286 \mathrm{~m}$ west of surface ground zero to changes in correlation scale. The value of $28.6 \mathrm{~m}$ is 10 percent of the transport domain (Gelhar, 1993), while sensitivity runs were made using two and five times that value.

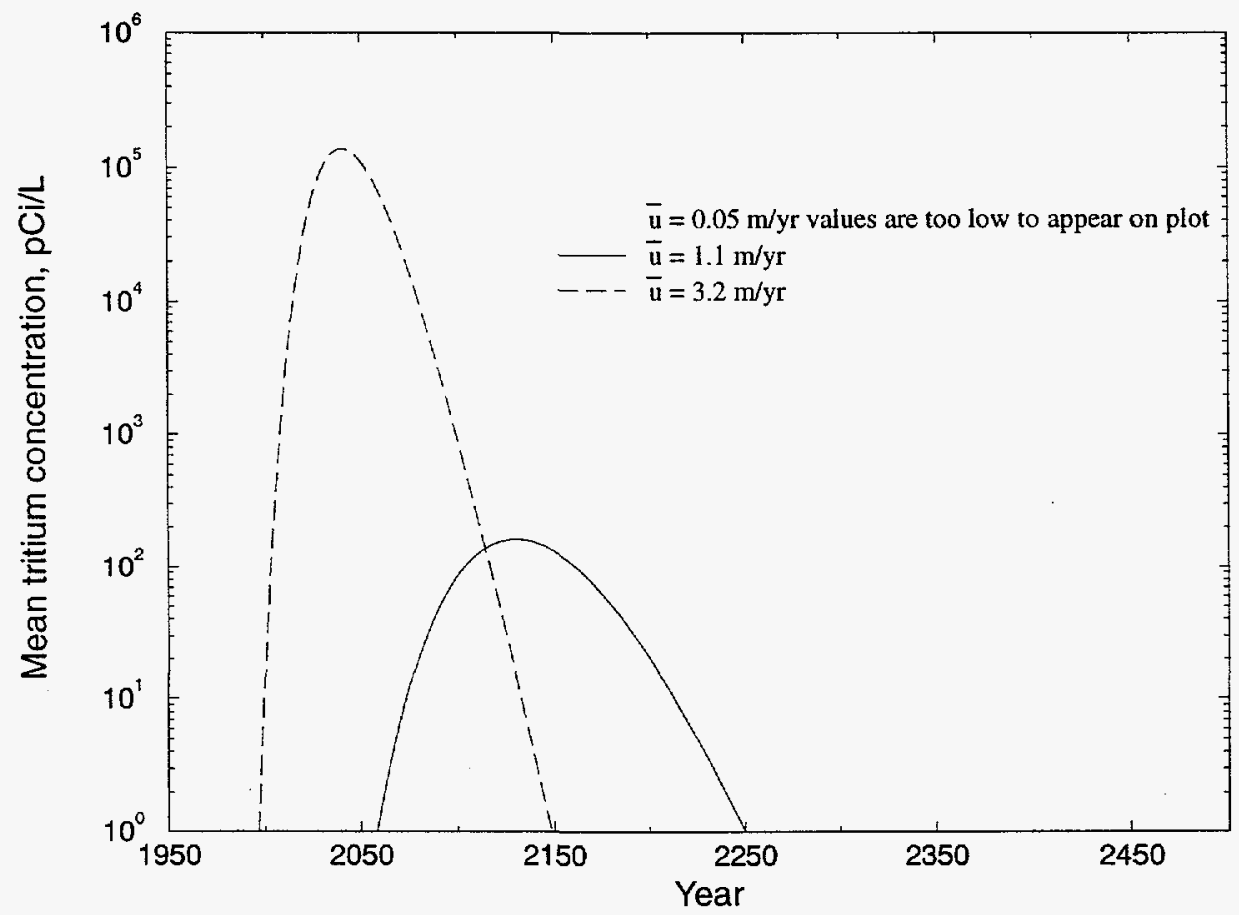

Figure 6. Sensitivity of mean tritium concentration $286 \mathrm{~m}$ northeast of surface ground zero to changes in mean groundwater velocity. The velocity of $1.1 \mathrm{~m} / \mathrm{yr}$ is value assumed for mean velocity at the site, based on the higher of two reported permeability values; the value of $0.05 \mathrm{~m} / \mathrm{yr}$ is based on the lower of the two permeability values, the value of $3.2 \mathrm{~m} / \mathrm{yr}$ is based on the higher of the two permeability values, in conjunction with an effective porosity of 0.03 . 


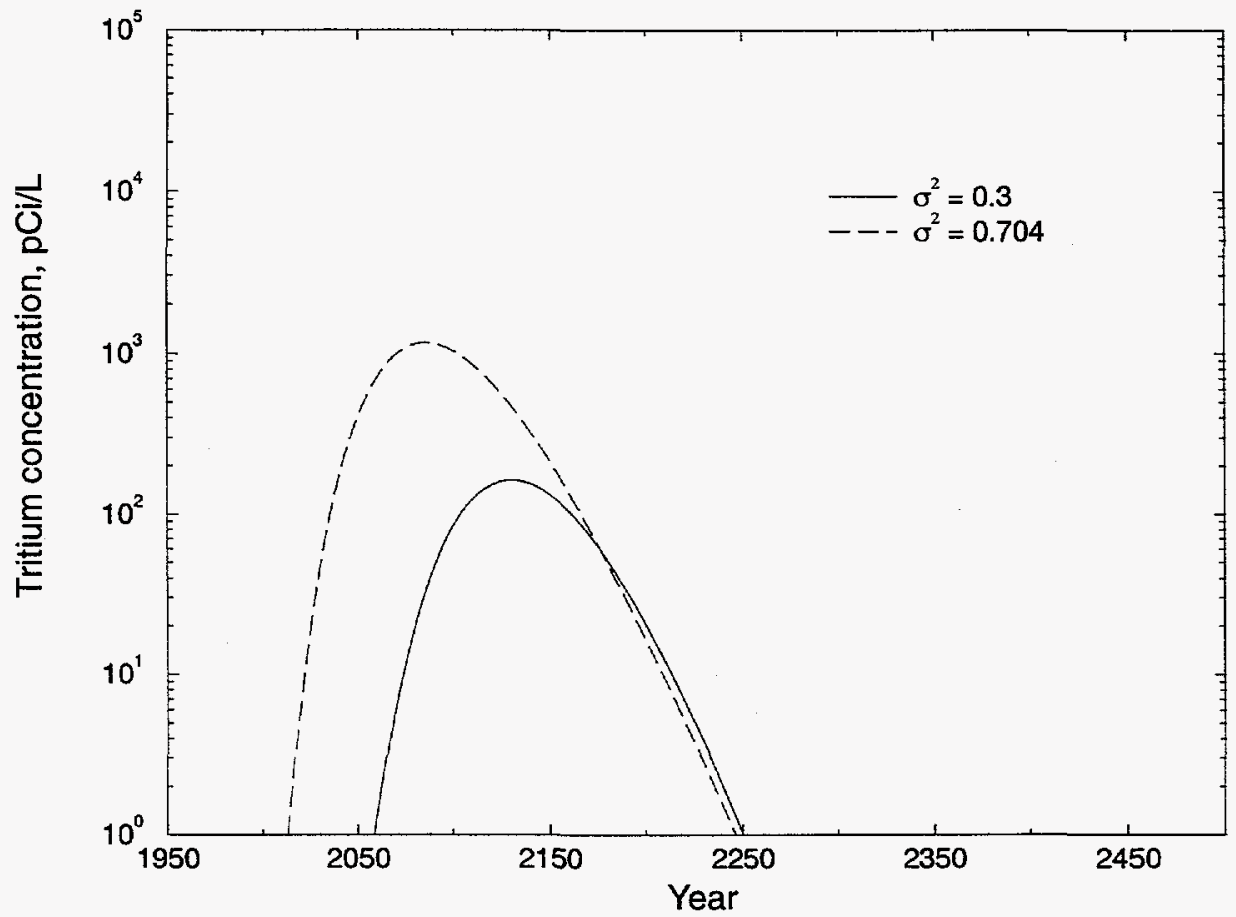

Figure 7. Sensitivity of mean tritium concentration $286 \mathrm{~m}$ northeast of surface ground zero to changes in variance. 0.3 is the median value for consolidated aquifers, while 0.704 is the highest value for a sandstone (both values from Hoeksema and Kitanidis, 1985).

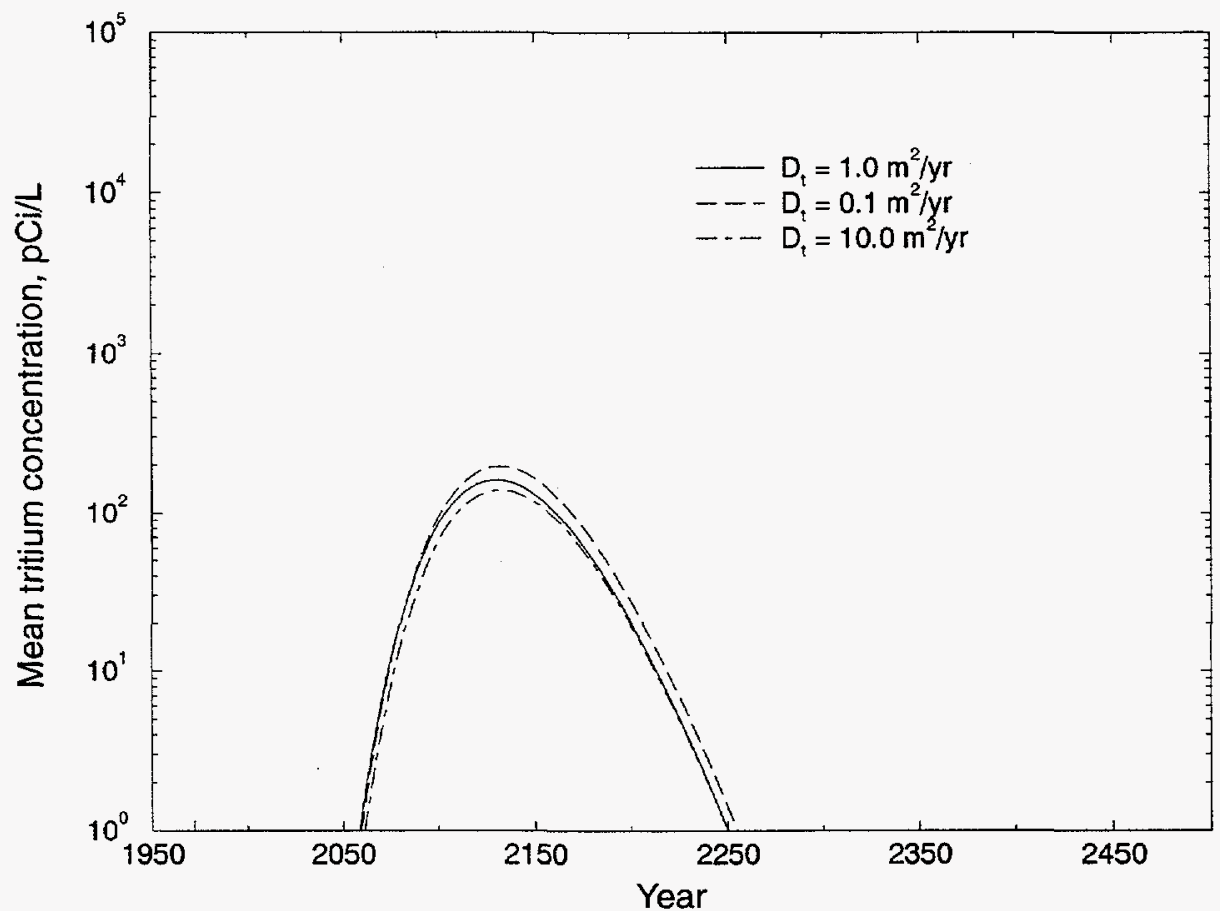

Figure 8. Sensitivity of mean tritium concentration $286 \mathrm{~m}$ northeast of surface ground zero to changes in the transverse hydrodynamic dispersion coefficient. One $\mathrm{m}^{2} / \mathrm{yr}$ is the best estimate of $D_{t}$ for the Rulison site, 0.1 and $10 \mathrm{~m}^{2} / \mathrm{yr}$ are one-tenth and ten times that value. 
control plane $195 \mathrm{yr}$ after the test at a concentration of $2.7 \times 10^{4} \mathrm{pCi} / \mathrm{L}$, with a peak mean concentration plus two standard deviations (providing a confidence level of 95 percent) of $4.5 \times 10^{4}$ $\mathrm{pCi} / \mathrm{L}$. Also assuming no sorption, ${ }^{137} \mathrm{Cs}$ has a peak mean concentration at the drilling exclusion boundary of $4.2 \times 10^{4} \mathrm{pCi} / \mathrm{L} 198 \mathrm{yr}$ after the test, and a peak mean concentration plus two standard deviations of $6.8 \times 10^{4} \mathrm{pCi} / \mathrm{L}$. The results of the non-sorption calculations show that the $K_{d}$ applied has a significant impact on the calculated transport of ${ }^{90} \mathrm{Sr}$ and ${ }^{137} \mathrm{Cs}$, but the highly conservative nature of the assumption that these nuclides are non-sorbing, as well as the other assumptions used in the modeling, should be kept in mind when evaluating the sensitivity results.

\section{DISCUSSION}

The EPA promulgated regulations in 1976 regarding radionuclides in community water systems through 40 CFR 141, the Primary Drinking Water Regulations. Part 141.16 describes the maximum contaminant levels for beta particle and photon radioactivity from man-made radionuclides in community water systems. Although no community water systems currently exist downgradient of the Rulison site, Part 141.16 provides a useful basis of comparison for the radionuclide concentrations calculated in the previous section.

The drinking water regulations actually limit the combined concentration of beta particle and photon radioactivity from man-made radionuclides to that producing less than an annual dose equivalent to the total body or any internal organ of 4 millirem/yr. Thus, the concentration limit for an individual radionuclide is influenced by the presence or absence of other radionuclides. For instance, the average annual concentration of ${ }^{3} \mathrm{H}$ assumed to produce a total body dose rate of 4 $\mathrm{mrem} / \mathrm{yr}$ is $20,000 \mathrm{pCi} / \mathrm{L}$ and the concentration of ${ }^{90} \mathrm{Sr}$ assumed to produce a dose rate of $4 \mathrm{mrem} / \mathrm{yr}$ to bone marrow is $8 \mathrm{pCi} / \mathrm{L}$. Those values would be the concentration limits only if either tritium or ${ }^{90} \mathrm{Sr}$ were the only man-made beta or photon emitter in the water (above detection). If both ${ }^{3} \mathrm{H}$ and ${ }^{90} \mathrm{Sr}$ are present, or if they are present with any other beta or photon emitter, the maximum concentration limits for each will be lower such that the combined dose rate remains below 4 $\mathrm{mrem} / \mathrm{yr}$.

The concentration limits where more than one radionuclide is concerned are obviously non-unique. For ease of reference, the $20,000 \mathrm{pCi} / \mathrm{L}$ guideline referred to for tritium is based on it being the only radionuclide present. It should be recognized that the release scenario considered for this study would result in the introduction into the Mesaverde of several other long-lived radionuclides, the presence of which would change the overall concentration guidelines.

It must also be kept in mind that the release scenario considered here is conservative; it is likely that the release of radionuclides from the cavity to the Mesaverde would be smaller than that used in the calculations. Some of the tritium mass is known to have been removed from the nuclear cavity during gas production testing, and many of the other radionuclides are expected to be in immobile phases. In addition, the results presented here are based on available data, which are extremely sparse. If the available values for transport parameters are not an accurate representation of conditions at the site, the results presented here could deviate significantly from reality.

The sensitivity analyses indicate that, given the ranges used for the hydraulic transport parameters, changes in the mean groundwater velocity $(0.05$ to $3.2 \mathrm{~m} / \mathrm{yr})$ cause a larger change in 
modeled concentration values ( $<1.0 \times 10^{-20}$ to $8.2 \times 10^{5} \mathrm{pCi} / \mathrm{L} 286$ m northeast of SGZ) than changes in the correlation scale ( 28.6 to $143 \mathrm{~m}$, yielding values from 1,240 to $21,500 \mathrm{pCi} / \mathrm{L}$ ), variance $(\ln K)$ ( 0.3 to 0.704 , yielding values from 1,240 to $3,900 \mathrm{pCi} / \mathrm{L}$ ), or the transverse hydrodynamic dispersion coefficient $\left(0.1\right.$ to $10 \mathrm{~m}^{2} / \mathrm{yr}$, yielding values from 1,730 to $\left.660 \mathrm{pCi} / \mathrm{L}\right)$. Thus, if a greater understanding of radionuclide transport from the Rulison site is desired, an accurate value for the mean groundwater velocity appears to be the most important piece of information to obtain, although the correlation scale and the variance $(\ln K)$ are important as well.

It is important to note that the sensitivity analyses were conducted by holding all parameters constant, except the one being examined. If the value for any parameter differs from the value used in the sensitivity analyses for the remaining parameters, then the relative importance of those parameters could be different than those suggested here.

At the Rulison site, tritium concentrations at the control plane appear to be highly sensitive to changes in the mean groundwater velocity. The high degree of sensitivity to this parameter is probably related to the extremely low groundwater velocity at the site. Although the distance to the control plane is less than $1 \mathrm{~km}$, when velocity is low, small changes in velocity can produce large changes in the time it takes for the centroid of the contaminant plume to reach the control plane. Because tritium is an unstable radionuclide with a half-life of $12.4 \mathrm{yr}$, at low velocities, even a small change in transport time can have a significant effect on total tritium mass by changing the number of half-lives required for the plume centroid to reach the control plane. It should be remembered that the Mesaverde Formation is not considered an aquifer in the Rulison area, and that the assumption of fully water-saturated conditions, required for the calculations presented here, is contradicted by site data. The presence of gas-filled zones within the Mesaverde would further retard transport in the aqueous phase by creating tortuous and disconnected water-filled pathways.

Although the sensitivity to changes in $K_{d}$ values was only examined for ${ }^{90} \mathrm{Sr}$ and ${ }^{137} \mathrm{Cs}$, it appears to be irrelevant for the remaining radionuclides, as they all had modeled peak mean concentrations plus two standard deviations at the drilling exclusion boundary that are less than the concentration causing a $4 \mathrm{mrem} / \mathrm{yr}$ dose rate, even without considering the effects of sorption. The sorption sensitivity calculations suggest that concentrations of ${ }^{90} \mathrm{Sr}$ and ${ }^{137} \mathrm{Cs}$ at the drilling exclusion boundary are sensitive to large changes in their $K_{d}$ values, and that sorption needs to be included in transport modeling or concentrations rise above regulatory levels.

\section{CONCLUSIONS}

The results of this study suggest that radionuclides from the Rulison test are totally contained within the Mesaverde Formation in the area currently administered by DOE. It should be kept in mind that these calculations were based on an assumption that the Mesaverde is water-saturated, and that the entire declassified mass of radionuclides produced by the test migrated out of the cavity. These results are meant to serve as the basis for discussion of possible transport scenarios and the need for further investigations at the Rulison site, not as definitive estimates of migration pathways or radionuclide concentrations.

The most critical factors affecting the transport calculations are the degree of water saturation of the Mesaverde, the amount of radionuclides released into the Mesaverde, and the values for the 
mean groundwater velocity, the correlation scale of hydraulic conductivity, and the variance in hydraulic conductivity $(\ln K)$ in the Mesaverde. Sorption is also important when considering migration of ${ }^{90} \mathrm{Sr}$ and ${ }^{137} \mathrm{Cs}$. If greater confidence in the calculations is needed, additional information on fracturing in the area surrounding the cavity, and an analysis of the likely disposition of radionuclides (gas phase, liquid phase, or solidified in melt products) should be obtained; in addition, an accurate quantification of values for the velocity, correlation scale, variance, and $K_{d}$ values for $\mathrm{Sr}$ and $\mathrm{Cs}$ should be undertaken. The radionuclide source term is an additional uncertainty in the calculations presented here, and can be addressed by considering classified data in future models.

\section{REFERENCES}

Andricevic, R. and V. Cvetkovic, 1996. Evaluation of risk from contaminants migrating by groundwater, Water Resources Research, 32(3), 611-621.

Andricevic, R., J.I. Daniels and R.L. Jacobson, 1994. Radionuclide migration using a travel time transport approach and its application to risk analysis, Journal of Hydrology, 163:125-145.

Austral Oil Company and CER Geonuclear, 1966. Project Rulison Feasibility Study, Report PNE-R-12.

Boysen, G.A., 1976. Off-Site Radiological Safety Program for Project Rulison Flaring, Phase III, U.S. Environmental Protection Agency, Las Vegas, Nevada, EMSL-LV-539-8.

Cvetkovic, V., G. Dagan and A.M. Shapiro, 1992. A solute flux approach to transport in heterogeneous formations, 2, Uncertainty analysis, Water Resources Research, 28:1377-1388.

Colorado Department of Health, 1980. Project Rio Blanco Environmental Surveillance Summary Report Part 2, July 1973-December 1976, Report PNE-RB-77 (Pt. 2).

Dagan, G., V. Cvetkovic and A. Shapiro, 1992. A solute flux approach to transport in heterogeneous formations 1. The general approach, Water Resources Research, 28(5):1369-1376.

Earman, S., J. Chapman and R. Andricevic, 1996a (in press). Assessment of hydrologic transport of radionuclides from the Gasbuggy underground nuclear test site, New Mexico, Desert Research Institute Water Resources Center Publication \#45148, DOE/NV/11508-16.

Earman, S., J. Chapman, K. Pohlmann, and R. Andricevic, 1996b (in press). Assessment of Hydrologic Transport of Radionuclides From the Gnome Underground Nuclear Test Site, New Mexico. Desert Research Institute, Water Resources Center Publication \#45143, DOE/NV/11508-11.

Eberline Instrument Corporation, 1977. Rulison Radiation Contamination Clearance Report, Eberline Instrument Corporation, Santa Fe, New Mexico, PNE-R-68.

Freeze, R.A. and J.A. Cherry, 1979, Groundwater, Prentice-Hall, Inc., Englewood Cliffs, New Jersey, 604p. 
Gelhar, L.W., 1993. Stochastic Subsurface Hydrology, Prentice Hall, Inc., Englewood Cliffs, New Jersey.

Hoeksema, R.J. and P.K. Kitanidis, 1985. Analysis of spatial structure of properties of selected aquifers, Water Resources Research, 21:563-572.

Hurr, R.T., W.W. Wilson, F.A. Welder and R.L. Emerson, 1969. Records of selected wells and springs in the Rulison Project area, Garfield and Mesa Counties, Colorado, U.S. Geological Survey, Denver, CO, USGS-474-40.

Larson, J.D. and W.A. Beetem, 1970. Chemical and radiochemical analysis of water from streams, reservoirs, wells, and springs in the Project Rulison area, Garfield and Mesa Counties, Colorado, U.S. Geological Survey, Denver, CO, USGS-474-67.

Nork, W.E., 1969. Radioactivity in the hydrologic environment, Project Rulison final pre-shot report, U.S. Atomic Energy Commission, NVO-1229-108.

Nork, W.E. and P.R. Fenske, 1970. Radioactivity in water--Project Rulison, Teledyne Isotopes, Palo Alto, California, NVO-1229-131.

Reynolds, M. Jr., 1971. Project Rulison post-shot investigations: Summary of re-entry operations, Austral Oil Company Incorporated, PNE-R-45.

Reynolds, M., Jr., B.G. Bray and R.L. Mann, 1970. Project Rulison: A preliminary report, in American Nuclear Society, 1970, Symposium on Engineering with Nuclear Explosives, pp. 597-628, CONF-700101 (Vol. 1).

Smith, D.K., B.K. Esser and J.L. Thompson, 1995. Uncertainties associated with the definition of a hydrologic source term for the Nevada Test Site, Lawrence Livermore National Laboratory, UCRL-ID-120322.

Stosur, J.J., 1977. Current status of Projects Gasbuggy, Rulison, and Rio Blanco and an appraisal of nuclear-explosive fracturing potential for the near future, in The Future Supply of Nature-Made Petroleum and Gas: Technical Reports, R.F. Meyer, ed., Pergamon Press, New York, pp. 697-721.

U.S. Atomic Energy Commission, 1972. Environmental Statement, Rio Blanco Gas Stimulation Project, Rio Blanco County, Colorado, U.S. Atomic Energy Commission, WASH-1519.

U.S. Atomic Energy Commission, 1973. Rulison Site Cleanup Report, U.S. Atomic Energy Commission, Las Vegas, Nevada, NVO-136.

U.S. DOE, 1984. Long-Term Hydrologic Monitoring Program, Rulison Event Site, Grand Valley, Colorado, U.S. Department of Energy, Las Vegas, Nevada, NVO-273.

U.S. Department of Energy, 1996. Rulison Site Corrective Action Report, U.S. Department of Energy, Nevada Operations Office, Las Vegas, Nevada, NVO-453. 
U.S. Energy Research and Development Administration, 1977. Project Rulison Well Plugging and Site Abandonment Final Report, NVO-187.

Voegeli, P. T., Sr. 1969. Geology and hydrology of the Project Rulison exploratory hole, Garfield County, Colorado, U.S. Geological Survey, Denver, CO, USGS-474-16.

Voegeli, P.T., Sr. and H.C. Claassen, 1971a. Radiochemical analysis of water from selected streams, wells, springs, and precipitation collected prior to reentry drilling, Project Rulison, U.S. Geological Survey, Denver, CO, USGS-474-83.

Voegeli, P.T., Sr. and H.C. Claassen, 1971b. Radiochemical analysis of water from selected streams, wells, springs, and precipitation collected during reentry drilling, Project Rulison, U.S. Geological Survey, Denver, CO, USGS-474-101.

Voegeli, P.T, Sr. and S.W. West, 1970. Geohydrology-Project Rulison, Garfield County, Colorado, U.S. Geological Survey, Denver, CO, USGS-474-68. 


\section{DISTRIBUTION}

Janet Appenzeller-Wing

Environmental Restoration Division

Nevada Operations Office

U.S. Department of Energy

P.O. Box 98518

Las Vegas, NV 89193-8518

Bob Bangerter

Environmental Restoration Division

Nevada Operations Office

U.S. Department of Energy

P.O. Box 98518

Las Vegas, NV 89193-8518

Joanne M. Bradbery, Director

Contract Management Division

Nevada Operations Office

U.S. Department of Energy

P.O. Box 98518

Las Vegas, NV 89193-8518

Beverly Colbert

Contract Management Division

Nevada Operations Office

U.S. Department of Energy

P.O. Box 98518

Las Vegas, NV 89193-8518

Frank Di Sanza, Director

Energy Technologies Division

Nevada Operations Office

U.S. Department of Energy

P.O. Box 98518

Las Vegas, NV 89193-8518

Doug Duncan

Hydrology Program Manager

Environmental Protection Division

Nevada Operations Office

U.S. Department of Energy

P.O. Box 98518

Las Vegas, NV 89193-8518
Paul Gretsky

International Technology Corporation

$4330 \mathrm{~S}$. Valley View

Suite 114

Las Vegas, NV 89103

Kenneth Hoar, Director

Environmental Protection Division

Nevada Operations Office

U.S. Department of Energy

P.O. Box 98518

Las Vegas, NV 89193-8518

Kathy Izell

Assistant Manager for Technical Services

Nevada Operations Office

U.S. Department of Energy

P.O. Box 98518

Las Vegas, NV 89193-8518

Roger Jacobson

Desert Research Institute

Water Resources Center

P.O. Box 19040

Las Vegas, NV 89132-0040

Marjory Jones

Desert Research Institute

Water Resources Center

P.O. Box 60220

Reno, NV 89506-0220

Jim Kannard

Bechtel Nevada Corporation

P.O. Box 98521

Las Vegas, NV 89193-8521

Randy Laczniak

U.S. Geological Survey

Water Resources Division

6770 S. Paradise Rd.

Las Vegas, NV 89119

Paul Liebendorfer

Division of Environmental Protection

State of Nevada

Capitol Complex

Carson City, NV 89710 
Frank Maxwell

Environmental Restoration Division

Nevada Operations Office

U.S. Department of Energy

P.O. Box 98518

Las Vegas, NV 89193-8518

Charles E. McWilliam, Director

Defense Projects Division

Nevada Operations Office

U.S. Department of Energy

P.O. Box 98518

Las Vegas, NV 89193-8518

Steve Mellington, Director

Environmental Restoration Division

Nevada Operations Office

U.S. Department of Energy

P.O. Box 98518

Las Vegas, NV 89193-8518

Leslie A. Monroe

Environmental Protection Division

Nevada Operations Office

U.S. Department of Energy

P.O. Box 98518

Las Vegas, NV 89193-8518

Peter Sanders

Environmental Restoration Division

Nevada Operations Office

U.S. Department of Energy

P.O. Box 98518

Las Vegas, NV 89193-8518

David K. Smith

Isotopes Sciences Division

Lawrence Livermore National Laboratory

P.O. Box 808, M/S L231

Livermore, CA 94550

Doug Trudeau

U.S. Geological Survey

Water Resources Division

6770 S. Paradise Rd.

Las Vegas, NV 89119

Annie Kelley

State Documents Department

Nevada State Library

Capitol Complex

Carson City, NV 89710
Archives

Getchell Library

University of Nevada, Reno

Beverly Carter

MacKay School of Mines Library

University of Nevada, Reno

Document Section, Library

University of Nevada, Las Vegas

4505 Maryland Parkway

Las Vegas, NV 89154

Library

Desert Research Institute

P.O. Box 60220

Reno, Nevada 89506-0220

Library

IT Corporation

4330 S. Valley View

Suite 114

Las Vegas, NV 89103

ATTN: Toni Miller

Library

Southern Nevada Science Center

Desert Research Institute

P.O. Box 19040

Las Vegas, NV 89132-0040

Technical Information Resource Center

Nevada Operations Office

U.S. Department of Energy

P.O. Box 98518

Las Vegas, NV 89193-8518

Public Reading Facility

Bechtel Nevada Corporation

P.O. Box 98521

Las Vegas, NV 89193-8521

Office of Scientific and Technical Information

U.S. Department of Energy

P.O. Box 62

Oak Ridge, TN 37831-9939 